\title{
The Effect of Multiple Intelligence(s) on Academic Success: A Systematic Review and Meta-analysis
}

\author{
Hasan Aydin 1* \\ ${ }^{1}$ Florida Gulf Coast University, Fort Myers, FL, USA
}

Received 14 April 2019 - Revised 26 April 2019 - Accepted 27 April 2019

\begin{abstract}
Many thesis, dissertations, and articles have been written on whether the concept of multiple intelligence has achieved the expected success in educational environments that has been established in accordance with the multiple intelligence principle and whether such developments have had a positive influence on the attitudes of students towards their learning. In other words, what kind of results do these scientific reports show? The research conducted in this paper seeks to determine the answer to this question through a meta-analysis and to determine if the creation and implementation of learning and teaching activities based on multiple intelligence models have had a positive influence on the academic success of students and have engendered positive attitudes towards learning. Within the context of this research, the following moderating factors were incorporated into the research; the level of education with which the studies dealt, the lesson under discussion, and the geographical region in which the studies were conducted and the year of publication of the studies concerned. These moderating factors did not seem to create any divergence in the results of the research regarding academic success. With respect to moderating factors, while no differences existed regarding the level of education, differences were observed in the relationship with the lessons, the geographical region and the academic year under observation within the studies.
\end{abstract}

Keywords: multiple intelligence, academic achievement, success, meta-analysis, systematic review

\section{INTRODUCTION}

Although the predominate view has been that intelligence could be measured objectively and stated using a single measure called IQ (Hoerr, 2000), Gardner (1983), who introduced the concept of multiple intelligence in his book Frames of Mind, believed that intelligence could not be measured by a single metric. Theoreticians/academics such as Gardner who had approached the topic have emphasized that intelligence was actually a phenomenon comprising multiple or plural elements.

Garner defined intelligence as the capacity employed by an individual or group in one or more cultural environments to create products of value or to solve problems (Ersoy \& Uysal, 2018; Gardner, 1983). In 1983, Gardner proposed the "multiple intelligence(s) theory" and brought about a new perspective for the issue of intelligence. According to Gardner (1993), intelligence encompasses many different abilities and has a multifaceted nature that cannot be expressed merely using a single number/measure or notion/concept. Gardner defined abilities that are found in different degrees in each individual as "intelligence areas" or "modalities". He named those intelligence modalities as follows: verbal-linguistic intelligence, logical-mathematical intelligence, visualspatial intelligence, musical-rhythmic and harmonic intelligence, bodily-kinesthetic intelligence, interpersonal intelligence, interpersonal intelligence and naturalistic intelligence. Although Gardner (1993) defined these eight intelligence areas, he noted that those eight areas of intelligence were insufficient to define fully the abilities of individuals and more areas of intelligence could be discovered in due course.

(C) 2019 by the authors; licensee Modestum Ltd., UK. This article is an open access article distributed under the terms and conditions of the Creative Commons Attribution License (http://creativecommons.org/licenses/by/4.0/). $\square$ haydin@fgcu.edu (*Correspondence) 


\section{Contribution of this paper to the literature}

- The structural relations in multiple Intelligences are synthesized meta-analytically.

- The concept of multiple intelligence has achieved the expected success in educational environments.

- The average effect size was calculated according to the random effect model.

- Moderating factors were observed in relationship with the lessons, the geographical region.

- Multiple Intelligence Theory influences academic success in a positive fashion.

Multiple Intelligence Theory represents the pluralist appearance of intelligence domains and the diversity of ways of expressing the skillfulness and skills of the individual within the scope of their own culture (Allen, 1997; Iyitoglu \& Aydin, 2015). According to Hopper and Hurry (2000), the theory of multiple intelligences could be adopted as an educational approach for many reasons. According to them, the multiple intelligence theory:

1. Ensures the development of consciousness in line with the learning processes of students;

2. Individualizes the learning process for every student; and

3. Provides for active learning.

To transfer these developments into school environments, teachers must be informed of developments regarding the issue and then to adopt them to their own practices. Whatever the extent is to which modern theories and well-designed educational programs may be developed, the person who will put these into practice is the teacher himself or herself.

The primary school program the Turkish Ministry of Education put into effect from 2005 was based on principles that focused on the thematic, constructivist, student-centered and student-active aspects of education. These programs were designed to allow for the scope of modern approaches such as the provision of teaching methods that teachers could apply that are sensitive to multiple intelligences and the individual differences of students (Gömleksiz, 2005). In the appendix (ces) of the Directive with Regard to the Planned Procedure of Education and Teaching found in Issue 2551 of the Educational Journal of Notifications/Announcements published by the Turkish Ministry of Education in August 2005, two examples were provided of lessons to be conducted with regard to these principles. Alterations were requested to be made so as to integrate the principles of Multiple Intelligence Theory. Thus, the assertion that multiple intelligence applications have occupied a significant position within the Turkish educational system over the course of the last ten years can be made. Additionally, many scientific studies have also been conducted on Multiple Intelligence(s) Theory that have assumed a prominent position within the educational system in Turkey.

Similar scientific research questions may be approached by different researchers using varying sample groups and sizes. In such a way, the results of studies conducted on similar topics may show similarities from time to time and at other times may exhibit differences. In such situations, those involved with the topic have felt a pressing need to look at the studies already conducted from a perspective that is more than that of a single researcher or research itself to reach a more suitable overview. Thus, the argument can be made that a meta-analysis may address this need.

This current study developed a synthesis of studies hitherto conducted in Turkey about the effect of the application of activities based on the Multiple Intelligence Theory on the academic success of the students involved and the attitudes of the respective students to the lessons. This was done to find answers to the following questions:

1. What is the difference between the success levels in lessons and at school of students who have undergone a process of teaching and learning based on Multiple Intelligence Theory and those who have undergone processes of learning based on traditional learning and teaching processes?

2. What is the difference between the attitudes to the lessons by students who have undergone a process of teaching and learning based on Multiple Intelligence Theory and those who have undergone processes of learning based on traditional learning and teaching processes?

3. What is the difference between the success of students in lessons with respect to moderating factors such as the level of education, the subject matter of a lesson, the geographical region and the year of study?

4. What is the difference between the attitudes of students towards lessons about moderating factors such as the level of education, the subject matter of a lesson, the geographical region and the year of study? 


\section{METHOD}

\section{Research Design}

This study employed a meta-analysis method. Meta-analysis may be defined as an analysis of empirical studies conducted on a particular topic or in similar fields that involve the grouping of the studies according to specific criteria and the combination of quantitative findings pertaining to these studies (Dincer, 2014; Erkuş, 2013; Hunter, Jackson, \& Schmidt, 1991). According to Cohen, Manion, and Morrison (2007), meta-analysis is, in simple terms, the "analysis of analyses". Glass and Petitti (2000) describe meta-analysis as the examination of effect sizes reported in study articles (as cited in Chambers, 2004). The application of meta-analysis offers the opportunity to create new models and theories that may present an overall perspective of studies already conducted in a particular academic field.

\section{The Criteria Required for Studies to Be Included Within the Scope of the Research}

The first stage when employing the meta-analysis method on academic studies that already have been conducted is to define clearly the criteria of selection for the studies to be included. The criteria and factors concerning whether studies should be incorporated in this current research are listed below. They are:

1. The inclusion of an experimental-control group design within the research study.

2. Deciding whether the individuals belonging to the experimental groups have undergone an educational process in a learning- and teaching-environment based on Multiple Intelligence Theory or supported by its principles.

3. Deciding whether those individuals found in the control group have undergone an educational process conducted in environments that could be described as traditional in nature.

4. Determining the definitions of the success and achievement of those belonging to the study group considered for the research.

5. Determining the $\square$ definitions of attitudes towards the lessons of those belonging to the study group.

6. The recording of the final test results from the experimental and control groups.

7. The clarity of arithmetical averages, standard deviations and numbers of participants for both the experimental and control groups.

8. An article or thesis has been submitted at the end of the scientific research process of the study.

9. The study was conducted in Turkey.

Studies that did not satisfy the conditions these criteria were not included within the scope of the research. As a result, 66 theses and 30 articles that met the criteria listed were incorporated into the scope of the research. The above-mentioned 96 studies were all conducted between 2001 and 2014.

\section{Data Collection}

The studies included within the research were all taken from the ProQuest Citations, EBSCO, and the Higher Academic Council (YÖK) and the National Thesis Search System databases from June to September 2015.

\section{Data Analysis}

The data obtained from the studies that met the criteria defined above were all loaded into the Comprehensive Meta-Analysis (CMA) software program.

Meta-analysis employs the effect size as its basic unit of measurement/evaluation. The most important aspect in the calculation of effect size is the degree of precision. The following factors influence the degree of precision, including variance, standard error, confidence interval, the homogeneity of the sample, the size of the sample and the research models employed (Borenstein, Hedges, Higgins, \& Rothstein, 2009). The most important question in this instance is: "What method was used to calculate the effect size?" These are: the fixed effect(s) model and the random effect(s) model.

In meta-analysis the goal defines the common/shared effect. Just as in all other statistical analyses the desire is that extreme values do affect the analysis. In meta-analysis an attempt is made to prevent extreme values from exerting a common effect on the results of research/studies. The fixed effect model assumes that the real effect size is the same for all studies included in the meta-analysis and that they share the same actual effect size (Borenstein, Hedges, Higgins, \& Rothstein, 2009. In the fixed effect model, the most important assumption is that "for all studies included in the meta-analysis there exists only one actual effect size" (Borenstein, Hedges, Higgins, \& Rothstein, 
2009: 78-79). However, the random effect model is based on the principle that the real effect size of factors such as the age of participants, the educational level of participants or the size of the class may differ from study to study (Üstün \& Eryllnaz, 2014). Because of the increase in the number of studies (with larger amounts of data), the contribution to the common/shared effect will not remain the same, and, therefore, the random effect model that aims to estimate the average of the distribution of the effect will not reach the same conclusion as that emanating from the fixed effect model. The random effect model, weights studies with small sample sizes in relationship to larger overall sample sizes, and, in such a way, that does not require a break from meta-analysis. Employing such a method allows for the provision of data about the common effects of other studies. In essence, such a state of affairs means that the random effect model is valid not merely for studies incorporating small sample sizes but for all types of academic studies (Aydin \& Aslan, 2016; Borenstein, Hedges, Higgins, \& Rothstein, 2009).

Another important statistical element that is used when choosing between a fixed and random effects model is that of the $Q$ notation. In analysis of the statistical value of $Q$, a hypothesis test is carried out to discover whether the general effect of all studies is shared or not. On analysis of the results, if the critical value (p) is found to fall below the critical values, then this result may be interpreted in such a way that "all studies do not share the general values". In such a situation, differentiation exists between the studies (Borenstein, Hedges, Higgins, \& Rothstein, 2009; Hedges \& Olkin, 1985: 124-128). The I² statistical value then provides information regarding the degree of this variation.

The publication bias of the studies included in the research was then analyzed using a funnel plot. In situations, in which no publication bias exists, a symmetry should be observed. Furthermore, the accumulation of elements on the internal and upper parts of the graph demonstrates that the contribution of the effect size is high. According to Cooper, Hedges, and Valentine (2009), if publication bias exists, then this leads to the emergence of an asymmetrical shape on the graph, and one corner of the graph remains empty with respect to another. In such a situation, the studies that contribute least to the common effect fall into the empty spaces at the bottom corners of the graph.

Moderating analysis is a method of analysis that provides for the testing of differences between the average effect sizes of moderating factors and the type of differences between sub-groups (Littel, Corcoran, \& Pillai, 2008; Ogurlu \& Sevim, 2017). The statistical significance in the difference between moderating factors are tested using the Q statistical method that Hedge and Olkin (1985) develop. In this method, the Q statistical measure is divided into two $Q_{\text {between }}\left(Q_{b}\right) f$ and $Q_{\text {within }}\left(Q_{w}\right)$; then, the analysis is then carried out using these two $Q$ figures. While $Q_{w}$ is used to test the homogeneity within the moderating factor itself, $\mathrm{Q}_{\mathrm{b}}$ is used to test the homogeneity between the groups (Borenstein, Hedges, Higgins, \& Rothstein 2009; Hedges \& Olkin, 1985).

In this study, the differences between the moderating factors were observed using the value $Q_{b}$. Four moderating factors were defined as being thought to exert an important effect on effect size. These were: 1) the level of education, 2) the lesson under discussion, 3) the geographical region and 4) the year of the study published.

\section{RESULTS}

The research was based on the main topic of the effect of learning and teaching environments based on or supported by the Multiple Intelligence Theory on student success and achievements and attitudes towards lesson. The breakdown of studies regarding the success and achievement of studies accepted for the meta-analysis are displayed in Table 1. 
Table 1. Information Concerning the Studies Included for Research with Regard to Student Achievement

\begin{tabular}{|c|c|c|}
\hline \multicolumn{2}{|c|}{ The number of studies included in the meta-analysis. } & 91 \\
\hline \multicolumn{2}{|c|}{ The size of the sample reached for the experimental group following analysis of all studies (NExperimental) } & 3210 \\
\hline \multicolumn{2}{|c|}{ The size of the sample reached for the control group following analysis of all studies ( $\left.N_{\text {control }}\right)$} & 3223 \\
\hline \multirow[t]{4}{*}{ Distribution of studies according to level of education } & Primary & 13 \\
\hline & Middle School & 50 \\
\hline & Secondary & 23 \\
\hline & Higher education & 5 \\
\hline \multirow[t]{4}{*}{ Distribution of studies according to subject areas } & Language Lessons & 10 \\
\hline & Numerical Disciplines (Science and Mathematics) & 59 \\
\hline & Humanities & 18 \\
\hline & Sports and Arts & 4 \\
\hline \multirow[t]{7}{*}{ Distribution of Studies according to geographic area } & Eastern Anatolia & 6 \\
\hline & Central Anatolia & 32 \\
\hline & Mediterranean & 9 \\
\hline & Aegean & 16 \\
\hline & South-Eastern Anatolia & 4 \\
\hline & Black Sea & 12 \\
\hline & Marmara & 12 \\
\hline \multirow[t]{2}{*}{ Distribution of studies according to year published } & $2001-2007$ & 72 \\
\hline & 2008 and Later & 19 \\
\hline
\end{tabular}

Table 2. Information on the Studies Concerning Attitudes Included Within the Research

\begin{tabular}{|c|c|c|}
\hline The number of studies included in meta-analysis & & 28 \\
\hline The size of the sample reached for the experimental grou & o following analysis of all studies ( $\left.N_{\text {Experimental }}\right)$ & 921 \\
\hline The size of the sample reached for the control group foll & wing analysis of all studies $\left(N_{\text {Experimental }}\right)$ & 849 \\
\hline The distribution of studies conducted according to level & Primary & \\
\hline of education & Middle School & 19 \\
\hline & Secondary Education & 4 \\
\hline Distribution of studies according to subject areas & Language Lessons & 3 \\
\hline & Numerical Disciplines (Mathematics and Science) & 16 \\
\hline & Humanities & 7 \\
\hline & Sports and Arts & 2 \\
\hline Distribution of studies according to geographical region & Central Anatolia & 10 \\
\hline & Mediterranean & 1 \\
\hline & Aegean & 8 \\
\hline & South Eastern Anatolia & 3 \\
\hline & Black Sea & 3 \\
\hline & Marmara & 3 \\
\hline Distribution of studies according to year of publication & $2001-2007$ & 25 \\
\hline & 2008 and later & 3 \\
\hline
\end{tabular}

In accordance with the criteria, 91 studies about success and achievement regarding multiple intelligence(s) were chosen for inclusion for analysis. These studies comprised 66 academic theses and 25 scientific articles. The number of studies conducted that focused on higher education was particularly limited. The studies were conducted predominantly in the field of the numerical and scientific disciplines (mathematics and science), were made in the Central Anatolian region, and were carried out between 2001 and 2007.

Yurt and Polat (2015) conducted a meta-analysis study comprising 66 theses and 7 scientific articles, concerning the effectiveness of multiple-intelligence applications on academic achievement. The section of this research study entitled Multiple Intelligence-The Effect on Achievement incorporates the studies forming part of the research that Yurt and Polat conducted. The general composition of the studies concerning attitudes that were included in the meta-analysis are shown in Table 2.

A total of 28 studies that satisfied the criteria specified were included in the research regarding attitudes of students. These studies were found predominantly to focus on numerical disciplines (science and mathematics), were in the main conducted in the Central Anatolian region and were carried out mostly between 2001 and 2007.

Saban (2009) found that taking 2007 as a starting point, 148 academic theses had been conducted on the topic of multiple intelligence in Turkey, with 27 of these (18.24\%) being written in English, 2 (1.35\%) in German, and the 
Table 3. Findings Concerning the Effect Size of the Meta-Analysis Conducted According to the Random Effect Model. (The Effect of Multiple Intelligence on Achievement)

\begin{tabular}{cccccc}
\hline $\begin{array}{l}\text { Number of } \\
\text { Studies }(\mathbf{N})\end{array}$ & $\begin{array}{c}\text { Size Effect } \\
\text { (ES) }\end{array}$ & Standard Error & $\mathbf{Z}$ & \multicolumn{2}{c}{ With a confidence interval of 95\% } \\
\hline 91 & 1.200 & 0.098 & $12.210^{\star \star *}$ & Lower limit & Upper limit \\
\hline
\end{tabular}

Note: ${ }^{*} \mathrm{p}<.05,{ }^{* \star} \mathrm{p}<.01$, and ${ }^{* * *} \mathrm{p}<.001$

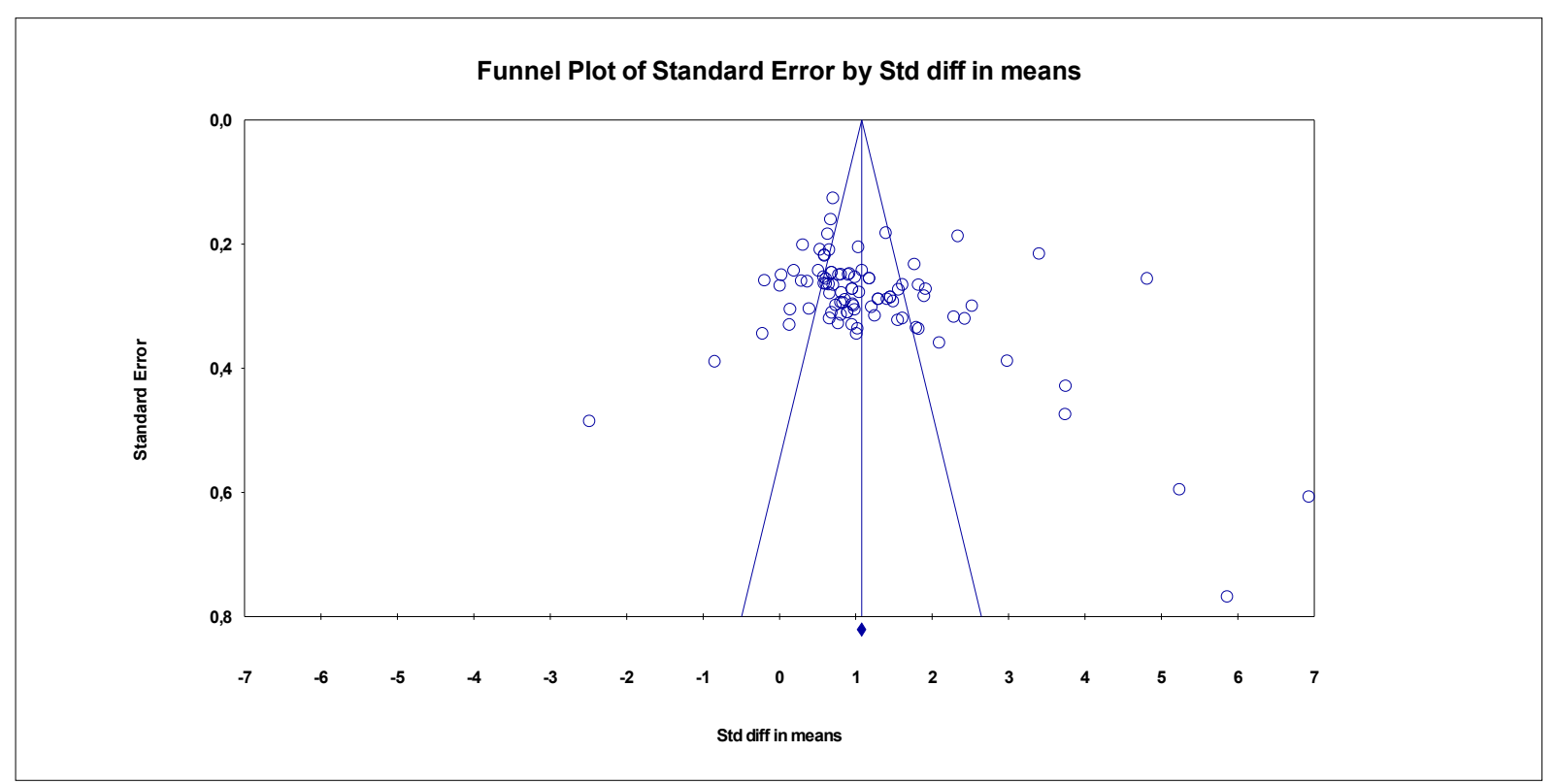

Figure 1. Funnel plot - meta-analysis for achievement

remaining $119(80.40 \%)$ in Turkish. However, these numbers include several studies that had not actually reached completion. Between 1999 and 2007, a total of 18 articles had been written and published in Turkish on the topic.

\section{The Effect of Activities Based on Multiple Intelligence Theory on Success and Achievement in Lessons}

Using meta-analysis, the general effect and publication bias was tested. The level of differentiation of the studies was examined to decide whether the fixed or random effect model would be more suitable for this current research. Because of the analysis conducted, 91 studies were $(Q(90)=1084,939, \mathrm{p}<.05)$ heterogeneous. The assumption of the $\mathrm{H}_{1}$ value was that the $\mathrm{Q}$ value was significant, and so the fact that the studies differed from one another was confirmed. The degree of heterogeneity (differentiation) was found to be $92 \%$. ( $\left.\mathrm{I}^{2}=\% 91,705\right)$. According to Cooper, Hedges, and Valentine (2009), in cases in which the $I^{2}$ value exceeds $75 \%$, this means that the studies under observation are heterogeneous to a high degree.

In cases in which studies are found to be heterogeneous, the random effect model provides more effective results regarding the calculation of the common effect size in meta-analysis calculations. The breakdown of the results of the analysis conducted using the random effect model and the accompanying forest plot is provided in Appendix 1. The results of the meta-analysis carried out in accordance with the random effect model are summarized in Table 3.

According to the results of the analysis that was conducted in accordance with the random effect model, the value of the size effect was found to be significant $(Z=12,210, p<.01)$ with a confidence interval of $95 \%$. The value of the average size effect was 1.200 and was found to be positive. Given such a case, the effect of the process could be said to be in favor of the experimental group. The success of individuals who had been educated in learning and teaching environments based on the Multiple Intelligence Theory was found to be higher than that of those who had not followed this approach.

The degree to which publication bias is present may be examined through a funnel plot (graph). The graph highlighting the publication bias present in this study is shown in Figure 1.

As can be seen in Figure 1, the studies included for this research are congregated in the upper and internal parts of the graph. Furthermore, the studies do not appear in a symmetrical formation on both sides of the graph. Studies that spill over from (fall outside) the outline shape of the graph are those that have least effect for the effect size 
Table 4. Findings Concerning the Effect Size of the Meta-Analysis Conducted According to the Random Effect Model (Multiple Intelligence-Effect on Attitude)

\begin{tabular}{|c|c|c|c|c|c|}
\hline \multirow{2}{*}{$\begin{array}{l}\text { Number of } \\
\text { Studies (N) }\end{array}$} & \multirow{2}{*}{$\begin{array}{l}\text { Effect Size } \\
\text { (ES) }\end{array}$} & \multirow{2}{*}{ Standard Error (SE) } & \multirow[b]{2}{*}{$\mathbf{Z}$} & \multicolumn{2}{|c|}{ Effect Size with Confidence Interval of $95 \%$} \\
\hline & & & & Lower Limit & Upper Limit \\
\hline 28 & 0,770 & 0,176 & $4,382^{* * *}$ & 0,426 & 1,115 \\
\hline
\end{tabular}

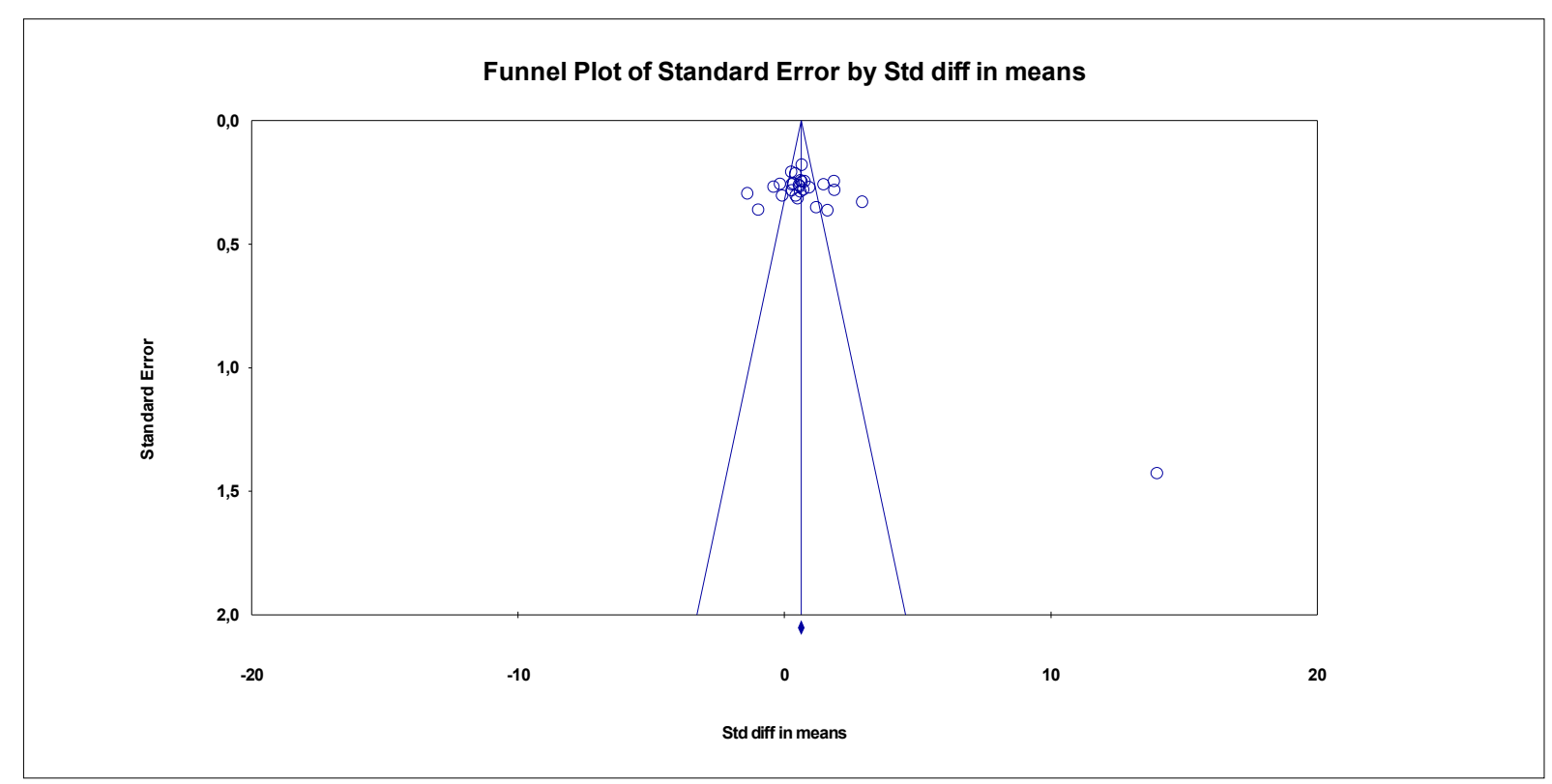

Figure 2. Funnel Plot Demonstrating the Degree of Publication Bias

and indicate deviation or bias. Deformation in the symmetry or shape of the graph represents an indication of publication bias.

To ascertain how many studies broke/distorted the symmetry of the graph, the Duval and Tweedie method was applied. According to this method, to achieve symmetry 23 studies had to be moved over to the right side of the graph. After carrying out this relocation of elements, the effect size was defined as 1.551. Thus, in a similar fashion to the meta-analysis research study that Yurt and Polat carried out in 2015, the studies included in this research were found to encompass a large degree of differentiation.

\section{The Effect of Multiple Intelligence Theory on Attitudes towards Lessons}

Using a meta-analysis method, the studies collected were analyzed for general effect and publication bias. Prior to deciding whether the fixed or random effect model would be chosen to analyses the data, the differentiation in the studies was analyzed. Because of the analysis conducted, 28 studies were found to be heterogeneous. In such a way, the $\mathrm{H} 1$ measure of assumption that the studies would differ from one another was confirmed as the $\mathrm{Q}$ variable was found to be significant. The degree of differentiation was found to be $91 \%(\mathrm{I} 2=\% 91,180)$. Several scholars indicated that cases in which the I2 variable exceeds 75\% show that the sample is heterogeneous to a large degree (Cooper, Hedges, \& Valentine, 2009; Karakus, 2018).

In cases in which the studies are found to be heterogeneous, meta-analysis conducted using the random effect model is seen to be more effective in providing reliable results regarding the calculation of the common effect size. The breakdown of the results of the analysis conducted using the random effect model and the accompanying forest plot are provided in Appendix 2. The results of the meta-analysis carried out in accordance with the random effect model are summarized in Table 4.

Because of analysis conducted according to the random effect model, the average effect size was found to be positive with a significant confidence interval of $95 \%(Z=4,382, p<.01)$. In such a situation, the effect of the process can be said to be in favor of the experimental group. Thus, individuals who had undergone a process of education in learning and teaching environments that are based on Multiple Intelligence Theory were seen to be more positive in their attitudes towards lessons than those who had not been exposed to such an approach in their education.

The degree to which publication bias is present in the research can be examined using a funnel plot. The graph that demonstrates the publication bias in this research study is shown in Figure 2. 
Table 5. The Effect of Multiple Intelligence on Success and Achievement in Lessons with Regard to Moderating Factors

\begin{tabular}{|c|c|c|c|c|c|c|c|c|c|}
\hline \multirow[t]{2}{*}{ Moderating Factor } & \multirow[t]{2}{*}{$\begin{array}{l}\text { Degree of Moderating } \\
\text { Factor }\end{array}$} & \multirow{2}{*}{$\begin{array}{c}\text { (N) } \\
\text { Number } \\
\text { of } \\
\text { Studies }\end{array}$} & \multirow[t]{2}{*}{$\begin{array}{l}\text { (ES) } \\
\text { Effect } \\
\text { Size }\end{array}$} & \multirow[t]{2}{*}{$\begin{array}{l}\text { (SE) } \\
\text { Standard } \\
\text { Error }\end{array}$} & \multirow[t]{2}{*}{$\mathbf{z}$} & \multicolumn{2}{|c|}{$\begin{array}{c}\% \\
\text { Effect Size with } \\
\text { Confidence } \\
\text { Interval of } 95 \%\end{array}$} & \multirow[t]{2}{*}{$\begin{array}{c}\mathbf{Q}_{\text {between }} \\
\left(\mathbf{Q}_{b}\right)\end{array}$} & \multirow[t]{2}{*}{ sd } \\
\hline & & & & & & $\begin{array}{c}\text { Lower } \\
\text { Limit }\end{array}$ & $\begin{array}{c}\text { Upper } \\
\text { limit }\end{array}$ & & \\
\hline \multirow{4}{*}{$\begin{array}{l}\text { Distribution of Studies } \\
\text { according to level of } \\
\text { education }\end{array}$} & Primary & 13 & 1.099 & 0.170 & $6.458^{* * *}$ & 0.766 & 1.433 & \multirow{4}{*}{1.018} & \multirow{4}{*}{3} \\
\hline & Middle School & 50 & 1.220 & 0.144 & $8.444^{\star \star \star}$ & 0.937 & 1.503 & & \\
\hline & Secondary & 23 & 1.278 & 0.210 & $6.076^{* * \star}$ & 0.866 & 1.690 & & \\
\hline & Higher Education & 5 & 0.990 & 0.264 & $3.757^{* * \star}$ & 0.473 & 1.508 & & \\
\hline \multirow{4}{*}{$\begin{array}{c}\text { Distribution of studies } \\
\text { according to fields of } \\
\text { study }\end{array}$} & $\begin{array}{c}\text { Dil Alanı Dersleri Language } \\
\text { Lessons }\end{array}$ & 10 & 1.315 & 0.292 & $4.496^{\star * \star}$ & 0.742 & 1.888 & \multirow{4}{*}{1.472} & \multirow{4}{*}{3} \\
\hline & $\begin{array}{c}\text { Numerical Disciplines } \\
\text { (mathematics and Science) }\end{array}$ & 59 & 1.121 & 0.129 & $8.717^{* * \star}$ & 0.869 & 1.373 & & \\
\hline & Humanities & 18 & 1.377 & 0.179 & $7.687^{* \star *}$ & 1.026 & 1.729 & & \\
\hline & Sports and Arts & 4 & 1.195 & 0.518 & $2.310^{\star}$ & 0.181 & 2.210 & & \\
\hline \multirow{7}{*}{$\begin{array}{l}\text { Distribution of studies } \\
\text { according to } \\
\text { geographical region }\end{array}$} & Eastern Anatolia & 6 & 1.254 & 0.356 & $3.524^{* * *}$ & 0.557 & 1.952 & \multirow{7}{*}{9.346} & \multirow{7}{*}{6} \\
\hline & Central Anatolia & 32 & 0.917 & 0.118 & $7.772^{\star \star \star}$ & 0.686 & 1.148 & & \\
\hline & Mediterranean & 9 & 1.774 & 0.317 & $5.595^{\star * \star}$ & 1.153 & 2.396 & & \\
\hline & Aegean & 16 & 1.286 & 0.254 & $5.067^{* \star \star}$ & 0.789 & 1.783 & & \\
\hline & South-Eastern Anatolia & 4 & 1.397 & 0.542 & $2.577^{\star}$ & 0.334 & 2.460 & & \\
\hline & Black Sea & 12 & 1.579 & 0.426 & $3.709^{\star \star \star}$ & 0.745 & 2.414 & & \\
\hline & Marmara & 12 & 1.011 & 0.255 & $3.968^{\star \star \star}$ & 0.512 & 1.511 & & \\
\hline \multirow{2}{*}{$\begin{array}{l}\text { Distribution of studies } \\
\text { according to year of } \\
\text { publication }\end{array}$} & $2001-2007$ & 72 & 1.206 & 0.109 & $11.019^{\star \star \star}$ & 0.991 & 1.420 & \multirow{2}{*}{0.016} & \multirow{2}{*}{1} \\
\hline & 2008 and later & 19 & 1.174 & 0.230 & $5.109^{* * *}$ & 0.724 & 1.624 & & \\
\hline
\end{tabular}

Note: ${ }^{*} \mathrm{p}<.05,{ }^{* \star} \mathrm{p}<.01$, and ${ }^{* \star \star} \mathrm{p}<.001$

As can be seen in Figure 2, the great majority of studies included in the research are collected in the upper part, while all of them are congregated in the internal part of the graph. Furthermore, the graph is not symmetrical on both sides of the graph. A distortion or a break in the symmetry represents an indication of publication bias. To ascertain how studies may break the inherent symmetry, the Duval and Tweedie Method was employed. According to this method to ensure symmetry, 23 studies needed to be moved to the right side of the graph. After carrying out this alteration, the effect size was calculated at 1.173. Considering this adjustment as the classification method of Cohen, Manionm, and Morrison (2007) suggested, a result may be reached that indicates a greater effect size than the one hitherto measured.

\section{Effect on Success and Achievement with Regard to Activities Based on Multiple Intelligence Theory and Attitudes to Lessons-Moderating Factors}

The success and achievement of individuals who had undergone a process of learning based on Multiple Intelligence Theory was analyzed to ascertain whether differences existed with respect to the level of education, the lesson subject, the geographical region and/or the year of publication. The results are summarized in Table 5 .

In an analogous manner, those individuals who had undergone a learning and teaching process based on Multiple Intelligence Theory were examined to see whether differences existed in terms of the level of education they had reached, lesson subjects, geographical region or year of study. The results are summarized in Table 6. 
Table 6. The Effect of Multiple Intelligence on Attitudes towards Lessons in Accordance with Moderating Factors

\begin{tabular}{|c|c|c|c|c|c|c|c|c|c|}
\hline \multirow{2}{*}{ Moderating factors } & \multirow{2}{*}{$\begin{array}{l}\text { Degree of Moderating } \\
\text { Factor }\end{array}$} & \multirow{2}{*}{$\begin{array}{c}\text { (N) } \\
\text { Number } \\
\text { of } \\
\text { studies }\end{array}$} & \multirow{2}{*}{$\begin{array}{l}\text { (ES) } \\
\text { Effect } \\
\text { Size }\end{array}$} & \multirow{2}{*}{$\begin{array}{c}\text { (SE) } \\
\text { Standard } \\
\text { Error }\end{array}$} & \multirow{2}{*}{$\mathbf{z}$} & \multicolumn{2}{|c|}{$\begin{array}{c}\text { Confidence Interval } \\
\text { of } 95 \% \\
\end{array}$} & \multirow{2}{*}{$\begin{array}{c}\mathbf{Q}_{\text {between }} \\
\left(\mathbf{Q}_{b}\right)\end{array}$} & \multirow{2}{*}{ sd } \\
\hline & & & & & & $\begin{array}{l}\text { Lower } \\
\text { Limit }\end{array}$ & $\begin{array}{l}\text { Upper } \\
\text { Limit }\end{array}$ & & \\
\hline \multirow{3}{*}{$\begin{array}{c}\text { Distribution of } \\
\text { studies with regard } \\
\text { to level of education }\end{array}$} & Primary & 5 & 0.652 & 0.311 & $2.096^{*}$ & 0.042 & 1.262 & \multirow{3}{*}{3.782} & \multirow{3}{*}{2} \\
\hline & Middle School & 19 & 0.952 & 0.245 & $3.888^{* * *}$ & 0.472 & 1.432 & & \\
\hline & Secondary & 4 & 0.283 & 0.242 & 1.171 & -0.191 & 0.758 & & \\
\hline \multirow{4}{*}{$\begin{array}{l}\text { Distribution of } \\
\text { studies according to } \\
\text { fields of study }\end{array}$} & Language lessons & 3 & -0.433 & 0.521 & -0.830 & -1.455 & 0.589 & \multirow{4}{*}{$9.789^{*}$} & \multirow{4}{*}{3} \\
\hline & $\begin{array}{c}\text { Numerical disciplines } \\
\text { (Science and Mathematics) }\end{array}$ & 16 & 1.040 & 0.231 & $4.497^{\star * *}$ & 0.587 & 1.493 & & \\
\hline & Humanities & 7 & 0.985 & 0.284 & $3.473^{\star \star}$ & 0.429 & 1.541 & & \\
\hline & Sports and Arts & 2 & -0.282 & 0.658 & -0.428 & -1.572 & 1.008 & & \\
\hline \multirow{5}{*}{$\begin{array}{c}\text { Distribution of } \\
\text { studies according to } \\
\text { Geographical Region }\end{array}$} & Central Anatolia & 10 & 0.619 & 0.234 & $2.646^{\star \star}$ & 0.160 & 1.077 & \multirow{5}{*}{$50.160^{\star * *}$} & \multirow{5}{*}{5} \\
\hline & Aegean & 8 & 0.532 & 0.243 & $2.186^{*}$ & 0.055 & 1.009 & & \\
\hline & South-Eastern Anatolia & 3 & -0.041 & 0.622 & -0.066 & -1.259 & 1.177 & & \\
\hline & Black Sea & 3 & 0.747 & 0.391 & 1.909 & -0.020 & 1.514 & & \\
\hline & Marmara & 3 & 4.015 & 1.205 & $3.331^{* *}$ & 1.652 & 6.377 & & \\
\hline \multirow{2}{*}{$\begin{array}{c}\text { Distribution of } \\
\text { studies according to } \\
\text { year of publication }\end{array}$} & 2001-2007 & 25 & 0.899 & 0.176 & $5.099 * * *$ & 0.554 & 1.245 & \multirow[b]{2}{*}{$4.476^{\star}$} & \multirow[b]{2}{*}{1} \\
\hline & 2008 and later & 3 & -0.372 & 0.575 & -0.648 & -1.499 & 0.754 & & \\
\hline
\end{tabular}

Note: ${ }^{*} \mathrm{p}<.05,{ }^{* *} \mathrm{p}<.01$, and ${ }^{* \star *} \mathrm{p}<.001$

On examining Table 5, the observation can be made that no significant difference in terms of moderating factors exists regarding the level of education, the lesson subject, the geographical region or the year of study of the publication of studies ( $p>$.05). No difference can be ascertained between the success in lessons between those students who underwent a learning-teaching process based on Multiple Intelligence Theory and those who had experienced traditional learning-teaching processes in terms of level of education, lesson subject, geographical region or year of publication of the studies.

On analysis of Table 6, the observation can be made that the level of education did not, as a moderating factor, create a significant difference on educational performance $(p>.05)$ while the lesson subject, the geographical region and the year of publication of the studies did render a significant difference as moderating factors $(\mathrm{p}<.05, \mathrm{p}<.01$, $\mathrm{p}<.05$ ). The findings regarding the attitudes of those students who had experienced a process of learning-teaching based on Multiple Intelligence Theory and those who had undergone a more traditional learning-teaching process were:

1. Little difference was found between studies regarding the different levels of education.

2. A difference was found in the studies carried out regarding different lessons. While little difference was recorded regarding attitudes towards language lessons or sports or arts lessons, difference in attitudes were discovered in the fields of the sciences and humanities. These differences in attitudes were in favor of the experimental group.

3. Differences in the studies were recorded regarding different geographical regions. While no differences in attitudes were found in South-East Anatolia and the Black Sea regions, in studies carried out in the Central Anatolian, Aegean and Marmara regions, differences in attitudes were discovered. These differences were in favor of the experimental group.

4. The studies differed according to the years in which they were conducted. While those studies carried out in 2008 and afterwards did not demonstrate differences in attitudes, those conducted between 2001-2007 showed noticeable differences. These differences were in favor of the experimental group.

\section{CONCLUSIONS AND RECOMMENDATIONS}

Before carrying out the meta-analysis for this research, the criteria for which studies were to be included in the research were stipulated. The research was conducted using a total of 91 studies that satisfied the stipulated criteria, 91 of which addressed the factor of success and 28 that dealt with the factor of attitude. These studies were related to a particular focus on the level of secondary/middle school, predominantly were focused on mathematics and science lessons, and were carried out predominantly in the Central Anatolian Region between 2001 and 2007.

The average effect size was calculated according to the random effect model. The reason for this was the apparent heterogeneity (differentiation/variation) in the studies. On analysis of the results, learning and teaching techniques based on Multiple Intelligence Theories were seen to have an effect on success, and those students 
subjected to such techniques were found to be more successful than those who had not undergone such a process with a confidence interval of $95 \%, Z=12,210, p<.01$. The value of the average effect size was calculated at 1.200 and found to be positive. Similar results were reached in the meta-analysis studies that Yurt and Polat (2005) conducted. The researchers determined that the academic success of the group that had been exposed to activities based on the Multiple Intelligence Theory was higher than that of the group for which traditional methods had been employed.

Applications based on Multiple Intelligence Theory were found to have an effect of a positive nature, and those students who had undergone such experiences were found to have more positive attitudes to learning than those who had not $(Z=4,382, p<.01$ with a confidence interval of $95 \%)$. The value of the average effect size was calculated at 0.7770 and designated as positive.

The effect sizes were calculated as part of this research, which when arranged according to the principles of classification that Cohen, Manion, and Morrison (2007) set out, were found to be either moderate or strong in nature.

According to the findings of the research, Multiple Intelligence Theory influences academic success in a positive fashion. Methods based on the principles of Multiple Intelligence Theory have been applied since the start of the 2000s. However, an examination of the performance of students on a country-wide basis in national examinations (level placement examinations at middle school level or at high school level for university entrance) reveals that a steady decline in the number of questions answered correctly and overall marks at such vital tests can be observed. Such a state of affairs gives pause for thought. The carrying out of detailed studies on this phenomenon may serve to bring more clarity to the issue.

As regards the effect size, the studies on an individual basis that have shown the greatest effect in favor of the experimental group with regard to the success of the application of multiple intelligence have been those conducted by the following researchers: Akcin (2009), Altinsoy (2011), Alegre Ansuátegui, Moliner, Miravet, Lorenzo, Valentín, and Maroto, (2018), Azap (2012), Babacan, (2006), Balim, Sahin-Pekmez, and Ozacik-Erdem (2004), Basli (2006), Bumen (2001), Cepni (2010), Dogan (2004), Gok-Altun (2006), Is1k (2007), Iflazoglu (2003), Karakoc (2006), Karakoc and Sezer (2007), Karatekin (2006), Korkmaz (2001), Korkmaz (2010), Koksal (2005), Koroglu and Yesildere (2004), Kurt and Temelli (2011), Kurt, Gumuş, and Gunay-Ermurat (2011), Kurtcuoglu (2007), Nacakci (2006), Ozacik-Erdem (2003), Saydam (2005), Sivrikaya and Kaya (2009), Sakir (2013), Sengül (2007), Tasezen (2005), Turkmen (2005), Turhan (2006), Uzunoz and Akbas (2011), Yagci (2006), Yavuz (2010), Yekrek (2006), Yildirim and Tarim (2008), Yildirim (2006), and Yildirim, Tarim, and İflazoglu (2006). The effect sizes of these studies can be seen to be significant. Because of a meta-analysis, the studies that favored the control group were also determined. These were the studies that Durmus-Hepyasar (2006) and Elmaci (2010) completed.

When examining the effect size of each study, the studies that were most in support of the experimental group regarding the effect of multiple intelligence applications on attitudes were Bumen (2001), Gazioglu (2006), İflazoglu (2003), Korkmaz (2001), Tasezen (2005), Turhan (2006) and Yekrek (2006). Considering the meta-analysis, the studies that also underlined the significant effect sizes in favor of the control group were those of Epcacan (2013) and Gorucu (2007).

The studies included within the scope of the research were distributed around the upper and internal parts of the graph and were spread in a symmetrical fashion on both sides of the graph. Furthermore, the studies that had little effect on the common effect and those that showed (publication) bias were also determined.

Within this current study, the moderating factors were taken to be level of education, the lesson subject that the study dealt with, the type of publication, the geographical region and the year of publication. None of these moderating factors were found to have a great effect on the success of the applications based on the Multiple Intelligence Theory. In Yurt and Polat (2015) and Carothers and Parfitt (2017)'s study, the educational levels were designated as primary and secondary education, and they found that no significant difference was registered regarding level of education. A comparison was also made with reference to the type of lesson, and this also rendered no significant difference in the findings of the research. The researchers also employed a different approach that used the duration of the experiment and the type of publication as moderating factors. They did not find any differences regarding the type of publication but did establish differences concerning the length of application of the experiment. Success was seen to rise as the duration of the application of the experiment was increased.

This situation is different with respect to studies conducted into attitudes towards learning. In the studies conducted concerning attitudes to learning the moderating factor of educational level did not create any difference. While multiple intelligence applications did not exert any influence on language lessons or for sports and arts, they did create difference in attitudes towards numerical and humanities disciplines. In addition, while there were no differences recorded in studies conducted in the South-Eastern Anatolian or Black Sea regions, differences in attitudes were observed in the Central Anatolian, Aegean and Marmara regions. These differences were in favor of the experimental group. 
Furthermore, no difference was recorded in attitudes in the studies in 2008 and later years, differences were found in the attitudes included in studies between 2001 and 2007. These differences were found to be in support of the experimental group. The years 2001 to 2007 were those in which applications based on the Multiple Intelligence Theory were first put into practice. In fact, from 2008 onward, applications have been based on the multiple intelligence system and/or the number of studies conducted after 2008 and that deal with this subject should easily be accessible for observation. This is because it is likely that, even within the group taken to be traditional learners, the group can be assumed on the part of those charged with putting new concepts into practice to have reached a certain maturity about exposure to applications based on Multiple Intelligence Theory. Moreover, the fact that an Educational Sciences Institute exists and that many master's/postgraduate students are accepted onto programs at universities situated in the Turkish capital of Ankara are also factors that influence the results of this research. This may be the reason why most of the studies included in this research have been conducted in the Central Anatolian region. The small number of studies carried out in the South-East Anatolian and the Black Sea regions may also be one reason why little significant differentiation is found between the studies in these regions.

A repetition or revision of this study may be suggested to enlarge its scope by including studies carried out abroad. Furthermore, this research could be conducted again taking into consideration only studies written in a thesis or an article format. In the case of such an endeavor being undertaken, it may also prove beneficial to revise the study, incorporating updates and developments from congresses and conferences.

\section{REFERENCES}

Acar, F. (2013). Yükseköğretimde yabanci dil öğretiminde çoklu zekâ kuramına dayalı olarak geliştirilen programın etkililiğinin değerlendirilmesi (Evaluating the effectiveness of the program developed based on the theory of multiple intelligences in foreign language teaching in higher education) (Unpublished master's thesis). Ankara Üniversitesi, Eğitim Bilimleri Enstitüsü, Ankara, Turkey.

Akçin, S. (2009). The effects of using activities based on Multiple Intelligence Theory on $11^{\text {th }}$ grade students' learning and retention of English vocabulary (Unpublished master's thesis). Dokuz Eylül Üniversitesi, Eğitim Bilimleri Enstitüsü, İzmir, Turkey.

Akman, N. (2007). Ortaöğretimde insanda destek ve hareket sistemi konusunun çoklu zekâ temelli işlenmesinin öğrenci başarısı üzerine etkisi (The effect of multiple intelligence-based processing of the humanitarian support and movement system in secondary education on student achievement (Unpublished master's thesis). Gazi Üniversitesi, Eğitim Bilimleri Enstitüsü, Yayınlanmamış, Ankara, Turkey.

Alaz, A. (2008). Çoklu zekâ temelli uygulamaların öğrencilerin coğrafya dersine karşı tutumlarına etkisi (Impact of multiple intelligence-based applications on students' attitudes towards geography lesson) Ahi Evran Üniversitesi, Kırşehir Eğitim Fakültesi Dergisi (KEFAD), 9(3), 113-123.

Alaz, A. (2009). Çoklu zekâ kuramı destekli eğitimin dokuzuncu sınıf coğrafya derslerinde başarıya etkisi (Success of multilevel theory-supported education in ninth grade geography lessons) Türk Ĕ̆itim Bilimleri Dergisi, $7(1), 1-22$.

Alegre Ansuátegui, F. J., Moliner Miravet, L., Lorenzo Valentín, G., \& Maroto, A. (2018). Peer tutoring and academic achievement in mathematics: a meta-analysis. Eurasia Journal of Mathematic Science and Technology Education, 14(1), 337-354. https:/ / doi.org/10.12973/ ejmste/79805

Allen, D. (1997). The effectiveness of multiple intelligence approach in a gifted social studies classroom (Unpublished master's thesis). Georgia College \& State University, Milledgeville, Georgia.

Altınsoy, A. B. (2011). Fen ve teknoloji dersinde çoklu zekâ kuramına dayalı öğretimin öğrencilerin başarılarına etkisi (Impact on students' achievement in teaching science and technology lesson based on multiple intelligence theory) (Unpublished master's thesis). Selçuk Üniversitesi, Eğitim Bilimleri Enstitüsü, Konya, Turkey.

Altuntaş, N. (2007). Çoklu Zekâ Kuramı İle Öğrenmenin 7. Sınıf Öğrencilerinin Matematik Başarılarına Etkisi (The influence of Multiple Intelligence Theory on the mathematical success of the 7th grade students (Unpublished master's thesis). Marmara Üniversitesi, Eğitim Bilimleri Enstitüsü, İstanbul, Turkey.

Ayaydın, A., \& Özsoy, V. (2011). Çoklu zekâ kuramı'na dayalı öğretimin ilköğretim 6. Sınıf resim-iş dersinde ögrenci tutumuna etkisi (Effect on student attitude in elementary 6th grade painting-work lesson based on multiple intelligence theory). Türk Ĕgitim Bilimleri Dergisi, 9(3), 497-518.

Aydin, H., \& Aslan, D. (2016). Reliability and validity testing of a new scale for measuring attitudes toward pedagogical teacher training. Journal of Education and Learning, 5(3), 1-9. https:/ / doi.org/10.5539/jel.v5n3p1

Aydogan, B. (2006). İlköğretim 7. Sını Matematik Derslerinde Çoklu Zekâ Kuramının Öğrenmeye, Öğrenmede Kahıcılığa Ve Matematiğg Olan Öğretmen ve Öğrenci Görüşlerine Etkisi (The effect of Multiple Intelligence Theory on teacher 
and student views on learning, retention and math in primary school 7th mathematics classes (Unpublished master's thesis). Eskişehir Osmangazi Üniversitesi, Fen Bilimleri Enstitüsü, Eskişehir, Turkey.

Azap, S. (2012). The effect of cooperative learning activities based on multiple intelligences theory on vocabulary learning in EFL classes (Unpublished master's thesis). Ondokuz Mayıs Üniversitesi, Eğitim Bilimleri Enstitüsü, Samsun, Turkey.

Azar, A., İrfan-Presley, A., \& Balkaya, Ö. (2006). Çoklu zekâ kuramına dayalı öğretimin öğrencilerin başarı, tutum, hatırlama ve bilişsel süreç becerilerine etkisi (Impact of learning based on multiple intelligence theory on students' achievement, attitude, recall and cognitive process skills). Hacettepe Üniversitesi, Eğitim Fakültesi Dergisi, 30, 45-54.

Babacan, Ş. (2006). Sosyal bilgiler 6. sinıf coğrafya ünitelerinden "Türkiye'miz" in öğretiminde işbirlikli yöntem destekli çoklu zekâ kuramının erişiye etkisi (Social information is the effect of accessibility of the cooperative method-supported multiple intelligence theory in the teaching of "Turkey" from the 6th grade geography units) (Unpublished master's thesis). Çanakkale on Sekiz Mart Üniversitesi, Sosyal Bilimler Enstitüsü, Çanakkale, Turkey.

Bak, Z. (2004). Çoklu zekâ kuramına dayalı rehber materyallerinin kimya başarısına etkisi (Impact of multi-intelligence theorybased guide materials on chemistry success) (Unpublished master's thesis). Karadeniz Teknik Üniversitesi, Fen Bilimleri Enstitüsü, Trabzon, Turkey.

Baki, A., Gürbüz, R., Ünal, S., \& Atasoy, E. (2009). Çoklu zekâ kuramına dayalı etkinliklerin kavramsal öğrenmeye etkisi: Tam sayılarda dört işlem Örneği (The effect of events based on multiple intelligence theory on conceptual learning: Four examples of operations in full numbers). Türk Eğitim Bilimleri Dergisi, 7(2), 237259.

Balım, A. G., Şahin-Pekmez, E., \& Özaçık-Erdem, M. (2004). Asitler bazlar konusunda çoklu zekâ kuramını'na dayalı uygulamaların öğrenci başarısına etkisi (The effect of multiple-intelligence-based practices on the success of students on basics of acids). Ege Ĕ̆itim Dergisi, 5(2), 13-19.

Başli, L. (2006). Çoklu zekâ kuramının coğrafya öğretiminde uygulanması ve öğrencilerin akademik başarısına etkisi (The application of multiple intelligence theory in geography teaching and its impact on the academic success of students) (Unpublished master's thesis) Marmara Üniversitesi, Eğitim Bilimler Enstitüsü, İstanbul, Turkey.

Bayrak, H. (2005). İlköğretim 8. sını öğrencilerinin kimyasal bağlar konusundaki başarılarına, öğrendikleri bilgilerin kalıcılı̆̆ına, tutum ve algılamalarına çoklu zekâ kuramına dayalı öğretimin etkisi (The effect of teaching based on multiple intelligence theory on the achievements of primary school 8th graders on chemical bonds, persistence of information they learn, attitudes and perceptions) (Unpublished master's thesis). Gazi Üniversitesi, Eğitim Bilimleri Enstitüsü, Ankara, Turkey.

Borenstein, M., Hedges, L. V., Higgins, J. P. T., \& Rothstein, H. R. (2009). Introduction to meta-analysis. Hoboken, New Jersey: John Wiley \& Sons Ltd. https:/ / doi.org/10.1002/9780470743386

Bozdeveci, Z. (2005). İlköğretim okulu 7. sını sosyal bilgiler dersi "Avrupa'da yenilikler" ünitesinde çoklu zekâ temelli ögretimin ögrenme ve hatırlama düzeyine etkisi (Afyonkarahisar ili örneği). (The effect of multiple intelligence-based instruction on the level of learning and remembering in the 7th grade social studies course "Innovations in Europe" elementary school: Afyonkarahisar province example) (Unpublished master's thesis). Erciyes Üniversitesi, Sosyal Bilimler Enstitüsü, Kayseri, Turkey.

Boztepe, İ. (2010). İlköğretim altıncı sınıf matematik dersi olasılık konusunda çoklu zekâ kuramının öğrenci başarı düzeyine etkisi (The effect of multiple intelligence theory on student achievement level on the probability of primary school sixth grade mathematics course) (Unpublished master's thesis). Gazi Üniversitesi, Eğitim Bilimleri Enstitüsü, Ankara, Turkey.

Bümen, N. (2001). Gözden geçirme stratejisi ile desteklenmiş çoklu zekâ kuramı uygulamalarının erişi, tutum ve kalıcılı̆̆a etkisiv (Impact of multiple intelligence theory applications supported by review strategy on access, attitude and permanence) (Unpublished doctoral dissertation). Hacettepe Üniversitesi, Sosyal Bilimler Enstitüsü, Ankara, Turkey.

Carothers, D., \& Parfitt, C. (2017). Disability or Language Difference: How Do We Decide? American Journal of Qualitative Research, 1(1), 1-12.

Çepni, O. (2010). İlköğretim 6. sınıf sosyal bilgiler dersi "ülkemizin kaynakları" ünitesinin çoklu zekâ kuramına göre ögretiminin öğrenci başarnsına etkisi (Kastamonu örneği) (Elementary 6th grade social studies course is influenced by student's "sources of our country" unit according to multiple intelligence theory) (Unpublished master's thesis) Gazi Üniversitesi, Eğitim Bilimleri Enstitüsü, Ankara, Turkey.

Chambers, E. A. (2004). An introduction to meta-analysis with articles from The Journal of Educational Research (1992-2002). The Journal of Educational Research, 98(1), 35-44. https://doi.org/10.3200/JOER.98.1.35-45 
Cihan, K. (2013). İlköğretim din kültürü ve ahlak bilgisi dersi ibadet konularının işlenişinde çoklu zekâ yaklaşımının ögrencilerin başarılar üzerindeki etkisi. (The primary religious culture and ethics lesson is the effect of multiple intelligence approaches on students' achievement in the processing of worship topics) (Unpublished master's thesis). Ondokuz Mayıs Üniversitesi, Sosyal Bilimler Enstitüsü, Samsun, Turkey.

Cohen, L., Manion, L., \& Morrison, K. (2007). Research methods in education (6 $6^{\text {th }}$ ed.). Abingdon, United Kingdom: Routledge. https:/ / doi.org/10.4324/9780203029053

Cooper, H., Hedges, L. V., \& Valentine, J. C. (2009). The handbook of research synthesis and meta-analysis (2nd ed.). Thousand Oaks, California: Sage Publications.

Demiral, Ü. (2006). Fen bilgisi öğretiminde genetik ünitesinin kavranmasında çoklu zekâ kuramının öğrenci başarısına etkisi (Impact of multiple intelligence theory on student achievement in understanding genetic unit in science teaching) (Unpublished master's thesis). Gazi Üniversitesi, Eğitim Bilimleri Enstitüsü, Ankara, Turkey

Demirel, Ö., Demir, K., Demirhan-İşcan, D., Tuncel, İ., \& Karacaoğlu, C. (2008). Çoklu zekâ kuramına dayalı etkinliklerin erişi, tutum ve ögrenmelerin kalıcılığına etkisi (Activities based on multiple intelligence theory influence access, attitude and permanence of learning). Bayburt Üniversitesi, Eğitim Fakültesi Dergisi, 3(I-II), $75-86$.

Dilek, F. N. (2006). Sekizinci sını öğrencilerinin fotosentez ve solunum konularını kavramalarına ve fene karşı tutumlarına çoklu zekâ modelinin etkisi (The effect of multiple intelligence models on the concept of photosynthesis and respiration in eighth grade students) (Unpublished master's thesis). Gazi Üniversitesi, Eğitim Bilimleri Enstitüsü, Fen Bilgisi Öğretmenliği Anabilim Dalı, Ankara, Turkey.

Dinçer, S. (2014). Eğitim bilimlerinde ygulamalı meta-analiz (Applied meta-analysis in educational sciences). Ankara, Turkey: Pegem Akademi. https:/ / doi.org/10.14527/pegem.001

Dinçer-Çengeloğlu, G. (2005). Çoklu zekâ kuramına göre düzenlenen hayat bilgisi dersi öğretim etkinliklerinin öğrenci başar ve tutumuna etkisi (Effect of lecture teaching activities organized according to multiple intelligence theory on student achievement and attitude) (Unpublished master's thesis). Abant İzzet Baysal Üniversitesi, Sosyal Bilimler Enstitüsü, Sınıf Öğretmenliği Anabilim Dalı, Bolu, Turkey.

Doğan, C. (2004). Çoklu zekâ teorisinin selçuk üniversitesi hazırlık okulu öğrencilerinin yazma performansına etkisi (The impact of multiple intelligence theory on the writing performance of students at the Selçuk University Preparatory School) (Unpublished master's thesis). Selçuk Üniversitesi, Sosyal Bilimler Enstitüsü, Konya, Turkey.

Doğan-Temur, Ö. (2001). Çoklu zekâ kuramına göre hazırlanan öğretim etkinliklerinin 4 sını öğrencilerinin matematik erişilerine ve ögrenilen bilgilerin kalıcılı̆̆ına etkisi. (The effect of teaching activities prepared according to the theory of multiple intelligence on the mathematical access of the 4 th grade students and the persistence of learned information) Unpublished master's thesis). Gazi Üniversitesi, Eğitim Bilimleri Enstitüsü, Ankara, Turkey.

Durmuş-Hepyaşar, L. (2006). Fizik dersinde çoklu zekâ ile öğretimin öğrenci başarısına katkısı ve öğrenci görüşleri (Contribution to student success in teaching physics with multiple intelligences and student views) (Unpublished master's thesis). Uludağ Üniversitesi, Sosyal Bilimler Enstitüsü, Bursa, Turkey.

Elmacı, M. T. (2010). Çoklu zekâ kuramına dayalı öğretimin ortaöğretim 9. sını biyoloji dersi canlıların temel bileşenleri konusunda öğrencilerin akademik başarısina etkisi (Elementary 9th grade biology lesson based on multi-intelligence theory influences students' academic achievement on the basic components of living things) (Unpublished master's thesis). Gazi Üniversitesi, Eğitim Bilimleri Enstitüsü, Ankara, Turkey.

Epçaçan, C. (2013). Çoklu zekâya dayalı etkinliklerin öğrencilerin okuma alışkanlığına ilişkin tutuma ve okuduğunu anlama özyeterlik algısına etkisi (The effect of multiple intelligence-based activities on students' reading habits and their reading comprehension and self-efficacy). Türkiye Sosyal Araştırmalar Dergisi, 17(1), 209-236. https:// doi.org/10.13159/susbid.47

Erkaçan, İ. (2006). Çoklu zekâ kuramının lise 1. sını öğrencilerinin ısı-sıcaklık, genleşme ve sıkıştırılabilirdik konusunu anlamalarına ve öğrendikleri bilgilerin kalıcilı̆̆ına etkisi (The effect of the theory of multiple intelligences on the understanding of heat-temperature, expansion and compressibility of first-year high school students and the permanence of information they learn) (Unpublished master's thesis). Gazi Üniversitesi, Eğitim Bilimleri Enstitüsü, Ankara, Turkey.

Erkuş, A. (2013). Davranış bilimleri için bilimsel araştırma süreci (4th ed.) (Scientific research process for behavioral sciences). Ankara, Turkey: Seçkin Yayıncılık.

Ersoy, E., \& Uysal, R. (2018). Opinions of School Psychological Counselors on Giftedness and Gifted Students' Education. American Journal of Qualitative Research, 2(2), 120-142.

Etli, C. (2007). Çoklu zekâ kuramına göre hazırlanan öğretim etkinliklerinin 9. sınıf öğrencilerinin biyoloji başarılarına ve ögrenilen bilgilerin kalıclĭğna etkisi (The impact of the 9th grade students' biology achievements and the persistence 
of learned information on teaching activities prepared according to multiple intelligence theory) (Unpublished master's thesis). Gazi Üniversitesi, Eğitim Bilimleri Enstitüsü, Ankara, Turkey.

Gardner, H. (1993). Frames of mind: The theory of multiple intelligences (2nd ed.). New York, New York: Basic Books.

Gazioğlu, G. (2006). İlköğretim 7. sinıf öğrencilerinin basınç konusunu kavramada çoklu zekâ tabanlı öğretimin öğrenci başarısl, tutumu ve öğrenilen bilgilerin kalıcllı̆̆ına etkisi (Impact of multi-intelligence-based teaching on the student's success, attitude and persistence of learned knowledge in the concept of pressure of 7 th grade primary school students) (Unpublished master's thesis). Gazi Üniversitesi, Ĕ̆itim Bilimleri Enstitüsü, Ankara, Turkey.

Gök-Altun, D. (2006). Çoklu zekâ kuramına göre hazırlanmış ses ve ışık ünitesinin öğrenci başarısına, hatırlama düzeylerine, fen bilgisine karşı tutumlarna ve öğretmen ve ögrenci görüşlerine etkisi (Impact of sound and light unit prepared according to multiple intelligence theory on student achievement, recall levels, attitudes towards science, and opinions of teachers and students) (Unpublished master's thesis). Muğla Üniversitesi, Fen Bilimleri Enstitüsü, Muğla, Turkey.

Gökçek, N. (2007). İlköğretim 8. sınıf öğrencilerinin asit baz konusundaki başarılarına çoklu zekâ kuramının etkisinin araştırlmast (Investigating the effect of multiple intelligence theories on the achievement of acid base in primary school 8th graders) (Unpublished master's thesis). Gazi Üniversitesi, Eğitim Bilimleri Enstitüsü, Ankara, Turkey.

Gömleksiz, M. N. (2005). Yeni ilköğretim programının uygulamadaki etkililiğinin değerlendirilmesi (Evaluation of the effectiveness of the new primary education program). Kuram ve Uygulamada Eğitim Bilimleri Dergisi, 5(2), 339-384.

Görücü, A. (2007). İlköğretim 7. sınıf beden eğitimi derslerinde işbirliğine dayalı öğrenim destekli çoklu zekâ kuramı uygulamalarını ögrencilerin performans, tutum ve ögrenilenlerin kalıcılı̆̆ına etkisi (The effect of multi-intelligence theory supported by cooperative learning in elementary 7th physical education classes on students' performance, attitude and permanence of learners (Unpublished doctoral dissertation). Selçuk Üniversitesi, Sosyal Bilimler Enstitüsü, Konya, Turkey.

Gözüm, A. İ. C. (2011). Çoklu zekâ kuramına göre işlenen enzimler konusunun fen bilgisi öğretmen adayları üzerindeki başartsinin incelenmesi (Investigation of the success of the enzymes studied according to the theory of multiple intelligence on science teachers' candidates) (Unpublished master's thesis). Kafkas Üniversitesi, Fen Bilimleri Enstitüsü, Kars, Turkey.

Güler-Karadeniz, N. (2006). Çoklu zekâ kuramı tabanlı öğretimin Anadolu Lisesi 9. sını öğrencilerinin İngilizce dersindeki başarılarına ve öğrenilen bilgilerin kalıcılı̆̆ına etkisi (The impact of multi-intelligence theory-based instruction on the success of English language lessons of 9th grade Anatolian High School students and the persistence of learned information) (Unpublished master's thesis). Süleyman Demirel Üniversitesi, Sosyal Bilimler Enstitüsü, Isparta, Turkey.

Güneş, R. S. (2006). İlköğretim 6. Sınıf öğrencilerinin duyu organları konusundaki başarılarına, öğrendikleri bilgilerin kahıcılığına ve tutumlarına çoklu zekâ kuramına dayalı öğretimin etkisi (The effect of teaching based on multiple intelligence theory on the achievements of primary school sixth graders on the sense organs, persistence of knowledge they learn and their attitudes) (Unpublished master's thesis). Gazi Üniversitesi, Eğitim Bilimleri Enstitüsü, Ankara, Turkey.

Gürçay, D., \& Eryılmaz, A. (2005). Çoklu zekâ alanlarına dayalı öğretimin öğrencilerin fizik başarısına etkisi (Impact of learning based on multiple intelligence areas on students' success in physics). Hacettepe Üniversitesi Eğitim Fakültesi Dergisi, 29, 103-109.

Hasenekoğlu, İ., \& Gürbüzoğlu, S. (2009). Çoklu zekâ kuramına dayalı işlenen protein sentezi konusunun öğrencilerin bilgilerindeki kalıcılığına etkisi (The effect of processed protein synthesis based on multiple intelligence theory on the persistence of students' knowledge). Ahi Evran Üniversitesi, Eğitim Fakültesi Dergisi, 10(3), 49-59.

Hedges, L. V., \& Olkin, I. (1985). Statistical methods for meta-analysis. Cambridge, Massachusetts: Academic Press Inc.

Hoerr, T. (2000). Becoming a multiple intelligences school. Washington, District of Columbia: Association of School Curriculum Development.

Hopper, B., \& Hurry, P. (2000). Learning the MI way: The effects on students' learning of using the theory of multiple intelligences. Pastoral Care in Education, 18(4), 26-32. https:/ / doi.org/10.1111/1468-0122.00176

İflazoğlu, A. (2003). Çoklu zekâ kuramı destekli kubaşık öğrenme yönteminin ilköğretim 5. Sınıf öğrencilerinin fen bilgisi dersindeki akademik başarı ve tutumlarına etkisi (The effect of cooperative learning method supported by multiple intelligence theory on the academic achievement and attitudes of the 5th grade students of science education (Unpublished doctoral dissertation). Çukurova Üniversitesi, Sosyal Bilimler Enstitüsü, Adana, Turkey. 
Işık, D. (2007). Çoklu zekâ kuramı destekli kubaşık öğrenme yönteminin ilköğretim dördüncü sınıföğrencilerinin matematik dersindeki akademik başarnlarna ve kalıcilığa etkisi The effect of cooperative learning method supported by multiple intelligence theory on the academic achievement and retention of mathematics class of fourth grade students (Unpublished master's thesis). Çukurova Üniversitesi, Sosyal Bilimler Enstitüsü, Adana, Turkey.

Işık, D., Tarım, K., \& İflazoğlu, A. (2007). Çoklu zekâ kuramı destekli kubaşık öğrenme yönteminin ilköğretim 3. sınıf öğrencilerinin matematik dersindeki akademik başarılarına etkisi (The effect of cooperative learning method supported by multiple intelligence theory on the academic achievement of mathematics class of 3rd grade students). Ahi Evran Üniversitesi Kırşehir Ĕ̆itim Fakültesi Dergisi (KEFAD), 8(1), 63-77.

İşık-Uçak, E. (2006). "Maddenin sınıflandırılması ve dönüşümleri" konusunda çoklu zekâ kuramı destekli öğretim yönteminin öğrenci başarısı, tutumu ve hatırda tutuma düzeyine etkisi (The effect of multi-intelligence theorysupported teaching method on "classification and transformation of the material" to student achievement, attitude and remembrance level) (Unpublished master's thesis). Pamukkale Üniversitesi, Fen Bilimleri Enstitüsü, Denizli, Turkey.

Iyitoglu, O., \& Aydin, H. (2015). The relationship between multiple intelligence profiles and reading strategy use of successful English as a Foreign Language (EFL) Readers. South African Journal of Education, 35(2), 1-21. https:/ / doi.org/10.15700/ saje.v35n2a980

Kaplan, A., \& Yılmaz, H. N. (2015). Çoklu zekâ kuramına uygun olarak hazırlanan etkinliklerin öğrencilerin akademik başarılarına ve kalıcılığa etkisi (The effectiveness of the activities prepared in accordance with the theory of multiple intelligence on the academic achievement and permanence of the students). Kazım Karabekir Eğitim Fakültesi Dergisi, 30, 59-70.

Kara, E. (2006). İlköğretim sekizinci sınıf fen bilgisi dersinde büyüme ve gelişme konusunda öğrencilerin başarıları, kavramaları ve tutumları üzerine çoklu zekâ modelinin etkisi (The effect of multiple intelligence models on the achievement, conception and attitudes of students on growth and development in elementary school eighth grade science class) (Unpublished master's thesis). Gazi Üniversitesi, Eğitim Bilimleri Enstitüsü, Ankara, Turkey.

Karakoç, İ. (2006). İlköğretim II. kademe sosyal bilgiler dersi coğrafya konularının öğretiminde çoklu zekâ uygulamalarının akademik başarn ve tutuma etkisi (Primary Education II. stage social studies course is the effect of academic achievement and holding on multiple intelligence applications in teaching geography subjects (Unpublished master's thesis). Niğde Üniversitesi, Sosyal Bilimler Enstitüsü, Niğde, Turkey.

Karakoç, İ., \& Sezer, A. (2007). İlköğretim II. kademe sosyal bilgiler dersi coğrafya konularının öğretiminde çoklu zekâ uygulamalarının akademik başarıya etkisi (Primary Education II. stage social science lesson effects the academic achievement of multiple intelligence applications in the teaching of geography subjects). Türkiye Sosyal Araştırmalar Dergisi, 11(2), 9-21.

Karakus, M. (2018). The Moderating Effect of Gender on the Relationships between Age, Ethical Leadership, and Organizational Commitment. Journal of Ethnic and Cultural Studies, 5(1), 74-84.

Karatekin, K. (2006). İlköğretim 4. sinıf sosyal bilgiler dersinde yön ve yön bulma yöntemleri konusunun çoklu zekâ kuramına göre öğretilmesinin öğrenci başarısına etkisi (The effect of teaching direction and direction methods in primary school th grade social studies lesson according to multiple intelligence theory) (Unpublished master's thesis). Gazi Üniversitesi, Eğitim Bilimleri Enstitüsü, Ankara, Turkey.

Kılıç-Demirkaya, E. (2006). İlköğretim okulu müzik derslerinde çoklu zekâ kuramı'na dayalı öğretimin 6. sınıföğrencilerinin başarısina ve öğrendikleri bilgilerin kalıcllı̆̆na etkisi (The success of 6th grade students based on multiple intelligence theory in primary school music lessons and the effect on the permanence of the information they learn) (Unpublished master's thesis). Abant İzzet Baysal Üniversitesi, Sosyal Bilimler Enstitüsü, Bolu, Turkey.

Kırmızı-Susar, F. (2006). İlköğretim 4. sınıf Türkçe öğretiminde çoklu zekâ kuramına dayalı işbirlikli öğrenme yönteminin erişi, tutumlar, öğrenme stratejileri ve çoklu zeka alanlar üzerindeki Etkileri (Cooperative learning method based on multiple intelligence theory in primary school 4 th grade Turkish language teaching has been used to determine access, attitudes, learning strategies and effects on multiple intelligence areas) (Unpublished doctoral dissertation). Dokuz Eylül Üniversitesi, Eğitim Bilimleri Enstitüsü, İzmir, Turkey.

Koç, E. S., \& Şahin, A. E. (2014). Çoklu zekâ kuramı ile desteklenmiş olan basamaklı öğretim programının öğrenci erişisine ve kalıcılığa etkisi (The impact of step-by-step instructional program supported by multiple intelligence theory on student access and retention). Eğitim ve Bilim, 39(174), 286-296.

Kocakara, G. (2010). The effect of multiple intelligence-based instruction on learning and attitudes of the sixth graders in English language teaching. Karadeniz Technical University (Unpublished master's thesis). The Institute of Social Sciences, Trabzon, Turkey.

Köksal, M. S. (2005). Solunum sistemleri konusunun çoklu zekâ kuramına dayalı öğretiminin, 10. sını öğrencilerinin derse karşı tutumu, akademik başarısı ve öğretimin kalıcılık düzeyine etkisi (The teaching of respiratory systems based on 
multiple intelligence theory, the attitude of 10th grade students towards the course, the academic success and the effect on the level of retention of teaching) (Unpublished master's thesis). Gazi Üniversitesi, Eğitim Bilimleri Enstitüsü, Ankara, Turkey.

Korkmaz, B. (2010). Ortaöğretim dokuzuncu sınıfbiyoloji dersi canlıların çeşitliliği ve sınıflandırılması ünitesinin çoklu zekâ temelli işlenmesinin öğrenci başarısı üzerine etkisi (The ninth grade biology lesson of secondary education is the diversity of living things and the effect of multiple intelligence-based processing of the classification unit on student achievement) (Unpublished master's thesis). Gazi Üniversitesi, Eğitim Bilimleri Enstitüsü, Ankara, Turkey.

Korkmaz, H. (2001). Çoklu zekâ kuramı tabanlı etkin öğrenme yaklaşımının öğrenci başarısına ve tutumuna etkisi (Effectiveness of effective learning approach based on multiple intelligence theory on student achievement and attitude, Ĕ̈itim ve Bilim, 26(119), 71-78.

Köroğlu, H., \& Yeşildere, S. (2004). İlköğretim yedinci sınıf matematik dersi tamsayılar ünitesinde çoklu zekâ teorisi tabanlı ögrretimin öğrenci başarısına etkisi (The effect of multi-intelligence theory-based instruction in student achievement in the 7th grade primary school mathematics course). Gazi Üniversitesi, Gazi Eğitim Fakültesi Dergisi, 24(2), 25-41.

Kuloğlu, S. (2005). Çoklu zekâ kuramının ilköğretim sekizinci sınıflarda matematik öğretiminde öğrenci başarısına etkisi (Effect of multiple intelligence theory on student achievement in mathematics teaching in elementary eighth grade) (Unpublished master's thesis). Balıkesir Üniversitesi, Fen Bilimleri Enstitüsü, Balıkesir, Turkey.

Kurt, M., \& Temelli, A. (2011). Üreme sistemleri konusunda uygulanan çoklu zekâ kuramının öğrencilerin akademik başarısına etkisi (Effect of multiple intelligence theory on reproductive systems to students' academic success). Ahi Evran Üniversitesi, Ĕ̆itim Fakültesi Dergisi, 12(1), 73-84.

Kurt, M., Gümüş, İ., \& Günay-Ermurat, D. (2011). Solunum sistemleri konusunda uygulanan çoklu zekâ kuramının öğrencilerin akademik başarısına etkisi (Effect of multiple intelligence theory on respiratory systems to students' academic success). Ĭğır Üniversitesi, Fen Bilimleri Enstitüsü Dergisi, 1(1), 39-44.

Kurtçuoğlu, S. (2007). Lise II. sınıf biyoloji dersi sindirim sistemi konusunda uygulanan çoklu zekâ kuramının öğrencilerin başarlarma etkisi (High School II. class biology course is the effect of multiple intelligence theory on the digestive system to students' success). (Unpublished master's thesis). Gazi Üniversitesi, Eğitim Bilimleri Enstitüsü, Ankara, Turkey

Kuşdemir-Kayıran, B., \& İflazoğlu, A. (2007). Çoklu zekâ kuramı destekli kubaşık öğrenme yönteminin türkçe dersine ilişkin tutuma ve okuduğunu anlama başarısına etkisi (The effect of cooperative learning method supported by multiple intelligence theory on the achievement of reading and understanding of Turkish lesson). Eurasian Journal of Educational Research, 29, 129-141.

Nacakcı, Z. (2006). Çoklu zekâ kuramı dayanaklı ders işleme modelinin ilköğretim 7. sınıf müzik dersinde öğrencilerin müziksel ögrenme düzeylerine etkisi (The effect of multi-intelligence theory based instructional model on musical learning levels of students in elementary 7th class music lesson) (Unpublished doctoral dissertation). Gazi Üniversitesi, Ĕ̆itim Bilimleri Enstitüsü, Ankara, Turkey.

Ogurlu, U., \& Sevim, M. N. (2017). The opinions of gifted students about leadership training. Journal of Ethnic and Cultural Studies, 4(2), 41-52.

Öner, M. (2005). Tam öğrenme destekli çoklu zekâ kuramı uygulamalarının fen bilgisi dersindeki erişi, tutum ve kalıcılı̆̆a etkisi (Effect of full learning supported multi-intelligence theory applications on access, attitude and permanence in science courses) (Unpublished master's thesis). Dicle Üniversitesi, Sosyal Bilimler Enstitüsü, Diyarbakır, Turkey.

Öngören, H. (2007). İlköğretim yedinci sınıffen bilgisi dersi "kuvvet, hareket ve enerji" ünitesinde çoklu zekâ kuramı tabanlı ögretimin öğrenci başarısı ve tutumları üzerindeki etkileri (The seventh grade elementary science course of elementary school "strength, movement and energy") (Unpublished master's thesis). Pamukkale Üniversitesi, Fen Bilimleri Enstitüsü, Denizli, Turkey.

Öngören, H., \& Şahin, A. (2008). Çoklu zekâ kuramı tabanlı öğretimin öğrencilerin fen bilgisi başarılarına etkileri (Multiple intelligence theory-based instruction for students to achieve science achievement). Pamukkale Üniversitesi, Eğitim Fakültesi Dergisi, 23, 24-35.

Oral, İ. (2006). Ortaöğretimde çoklu zekâ kuramının elektrik konuların öğrenme sürecine etkisinin araştırılması (Investigation of the effect of multiple intelligence theory on the learning process of electrical topics in secondary education) (Unpublished master's thesis). Selçuk Üniversitesi, Fen Bilimleri Enstitüsü, Konya, Turkey.

Öz, C. (2005). İlköğretim 6. sınılarda kesirler konusunun çoklu zekâ kuramına uygun öğretiminin başarıya etkisi (The success effect of proper teaching of fractions in the sixth grade of elementary school on multiple intelligence theory) (Unpublished master's thesis). Marmara Üniversitesi, Eğittim Bilimleri Enstitüsü, İstanbul, Turkey. 
Özaçık-Erdem, M. (2003). İlköğretim 8. sınıf asit baz konusu üzerine çoklu zekâ kuramı uygulamalari (Multiple intelligence theory applications on the 8th grade elementary school acid base topic) (Unpublished master's thesis). Dokuz Eylül Üniversitesi, Eğitim Bilimleri Enstitüsü, İzmir, Turkey.

Özyılmaz-Akamca, G. (2003). İlköğretim beşinci sınıf fen bilgisi dersi ısı ve ısının maddedeki yolculuğu ünitesinde çoklu zekâ kuramı tabanlı ögretimin öğrenci başarısı, tutumu ve hatırda tutma üzerindeki etkileri (Elementary fifth grade science lesson: The effect of multiple intelligence theory-based instruction on student achievement, attitude and remembrance of heat and heat on the journey unit) (Unpublished master's thesis). Dokuz Eylül Üniversitesi, Eğitim Bilimleri Enstitüsü, İzmir, Turkey.

Pekderin, S. (2006). The effectiveness of multiple intelligences activities on vocabulary learning in elementary classes (Unpublished master's thesis). Çanakkale Onsekiz Mart University, Institute of Social Sciences, Çanakkale, Turkey.

Petitti, D. B. (2000). Meta-analysis, decision analysis, and cost-effectiveness analysis, methods for quantitative synthesis in medicine (2nd ed.). New York, New York: Oxford University Press.

Saban, A. (2009). Çoklu zekâ kuramı ile ilgili Türkçe çalışmaların içerik analizi (Content analysis of Turkish studies on multiple intelligence theory). Kuram ve Uygulamada Ĕgitim Bilimleri (Educational Sciences: Theory $\mathcal{E}$ Practice), 9(2), 833-876.

Şakir, T. (2013). The effect of multiple intelligences based instruction on students' achievement in basic compounds of living organism's concepts and attitude toward biology (Unpublished doctoral dissertation). Middle East Technical University, Ankara, Turkey.

Şalap, N. (2007). Çoklu zekâ kuramına dayalı etkinliklerin öğrenci başarısına etkisi: Hücre bölünmeleri (Effect of activities based on multiple intelligence theory on student achievement: cell divisions). (Unpublished master's thesis). Gazi Üniversitesi, Eğitim Bilimleri Enstitüsü, Ankara, Turkey.

Saydam, E. (2005). Çoklu zekâ kuramına göre hazırlanmış öğrenme ortamlarının 6. sınıf öğrencilerinin matematik başarlarına etkisi (Effect of mathematical achievements of sixth grade students on learning environments prepared according to multiple intelligence theory) (Unpublished master's thesis). Marmara Üniversitesi, Fen Bilimleri Enstitüsü, İstanbul, Turkey.

Şengül, S. H. (2007). Çoklu zekâ kuramı temelli öğretimin ilköğretim altıncı sını öğrencilerinin dolasım sistemi başarıları üzerine etkisi (Effect of multi-intelligence theory-based teaching on the circulation system success of primary school sixth graders) (Unpublished master's thesis). Balıkesir Üniversitesi, Fen Bilimler Enstitüsü, Balıkesir, Turkey.

Şengül, S., \& Öz, C. (2006). İlköğretim 6. sınıf kesirler ünitesinde çoklu zekâ kuramına uygun öğretimin matematik başarı ve kalıcılığa etkisi (The effect of mathematical success and retention on the teaching of multiple intelligences in elementary 6th grade fractional unit). M.Ü. Atatürk Eğitim Fakültesi Ĕ̆itim Bilimleri Dergisi, 24, 163-177.

Şengül, S., \& Öz, C. (2008). İlköğretim 6. sınıf kesirler ünitesinde çoklu zekâ kuramına uygun öğretimin öğrenci tutumuna etkisi (Effect of teaching according to multiple intelligence theory in elementary 6th grade fraction unit). İlköğretim Online, 7(3), 800-813.

Sivrikaya, A, H., \& Kaya, M. (2009). Çoklu zekâ kuramına dayalı öğretim yönteminin sınıf öğrencilerinde beden eğitimi dersi başarısına etkisi (Effect of teaching method based on multiple intelligence theory to achievement of physical education course in class). Atatürk Üniversitesi, Beden Eğitimive Spor Yüksek Okulu Dergisi (ATABESBD), 11(2), 21-34.

Tabuk, M., \& Özdemir, A. Ş. (2009). Proje tabanlı öğrenmede çoklu zekâ yaklaşımının matematik öğrenme başarısına etkisi (The impact of multiple intelligence approaches on project-based learning to the success of mathematics learning). International Online Journal of Educational Sciences, 1(1), 177-195.

Tabuk, M., \& Özdemir, A. Ş. (2010). Proje tabanlı öğrenmede çoklu zekâ yaklaşımının öğrencilerin matematiğe karşı tutumlarına etkisi (Multi-intelligence approach to project-based learning impacts students' attitudes towards mathematics). E-Journal of New World Sciences Academy, 5(3), 674-686.

Taşezen, S. S. (2005). Çoklu zekâ kuramına göre hazırlanan öğretim etkinliklerinin erişiye, kavram öğrenmeye ve tutuma etkisi (Effects of access, concept learning and holding on teaching activities prepared according to multiple intelligence theory) (Unpublished master's thesis). Marmara Üniversitesi, Eğitim Bilimleri Enstitüsü, İstanbul, Turkey.

Tertemiz, N. (2004). Çok zekâ kuramı́na göre bütünleştirilmiş etkinliklerin öğrenci başarısı üzerindeki etkisi (According to the theory of intelligence, the effect of integrated events on student achievement). Eğitim ve Bilim, 29(134), 1-10.

Turhan, E. A. (2006). İlköğretim 8. sinıf öğrencilerinin fen bilgisi öğretiminde mıknatıs ve özellikleri konusunu kavramada çoklu zekâ modelinin öğrenci başar ve tutumuna etkilerinin araştırılması (Investigation of the effects of multiple intelligence models on student achievement and attitude in the concept of magnetism and properties in primary school 
8th grade students' science teaching) (Unpublished master's thesis). Gazi Üniversitesi, Eğitim Bilimleri Enstitüsü, Ankara, Turkey.

Türkmen, N. (2005). "Canlılar ve doğayla etkileşimleri" ünitesine yönelik çoklu zekâ kuramı tabanl rehber materyal geliştirilmesi ve ögrretim sürecindeki etkililigi (The development of multi-intelligence theory-based guide material for the "Interactions with creatures and nature" unit and the effectiveness of the teaching process) (Unpublished doctoral dissertation). Karadeniz Teknik Üniversitesi, Fen Bilimleri Enstitüsü, Trabzon, Turkey.

Türkuzan, R. (2004). Çoklu zekâ kuramının lise 1. sını öğrencilerinin öz kütle konusunu anlamalarına ve öğrendikleri bilgilerin kalıcilı̆gına etkisi (The effect of the theory of multiple intelligence on the perception of the self-mass of the first-year high school students and the permanence of the information they learn) (Unpublished master's thesis). Gazi Üniversitesi, Eğitim Bilimleri Enstitüsü, Ankara, Turkey.

Üstün, U., \& Eryılmaz, A. (2014). Etkili araştırma sentezleri yapabilmek İçin bir araştırma yöntemi: Meta-analiz (A research method for effective research synthesis: Meta-analysis). Eğitim ve Bilim, 39(174), 1-32. https:/ / doi.org/10.15390/EB.2014.3379

Uzunöz, A., \& Akbaş, Y. (2011). Coğrafya dersinde çoklu zekâ destekli öğretimin öğrenci başarısı ve kalıcılığa etkisi (Impact of multi-intelligence assisted instruction in geography course on student success and permanence). Türk Ĕ̆itim Bilimleri Dergisi, 9(3), 467-496.

Yağcı, Z. (2006). Çoklu zekâ kuramının ilköğretim altıncı sınıf fen bilgisi öğretiminde öğrenci başarısına etkisi (The effect of multiple intelligence theory on student achievement in elementary school sixth grade science teaching) (Unpublished master's thesis) Balıkesir Üniversitesi, Fen Bilimleri Enstitüsü, Balıkesir, Turkey.

Yavuz, B. (2010). The effects of multiple intelligences activities on vocabulary achievement and attitudes of learners of English (Unpublished doctoral dissertation). Dokuz Eylül Üniversitesi, Eğitim Bilimleri Enstitüsü, İzmir, Turkey.

Yekrek, Ş. (2006). İlköğretim sekizinci sınıf T.C. inkılap tarihi ve Atatürkçülük dersinde çoklu zekâ kuramının öğrencilerin erişisine ve derse karşı tutumuna etkisi (Primary eighth grade T.C. the history of revolution and the influence of multiple intelligence theory on the access of students and attitudes towards class in the course of Ataturk) (Unpublished master's thesis) Abant İzzet Baysal Üniversitesi, Sosyal Bilimler Enstitüsü, Bolu, Turkey.

Yıldırım, K. (2006). Çoklu zekâ kuramı destekli kubaşık öğrenme yönteminin ilköğretim 4. sınıf öğrencilerinin matematik dersindeki erişilerine etkisi (The effect of cooperative learning method supported by multiple intelligence theory on access to mathematics lesson of primary 4th grade students). Ahi Evran Üniversitesi, Kırşehir Eğitim Fakültesi Dergisi (KEFAD), 7(2), 301-315.

Yıldırım, K. (2006). Çoklu zekâ kuramı destekli kubaşık öğrenme yönteminin ilköğretim 5. sını öğrencilerinin matematik dersindeki akademik başar, benlik saygisı ve kalıcılığına etkisi (The effect of cooperative learning method supported by multiple intelligence theory on academic achievement, self-esteem and permanence in the mathematics class of the 5th grade primary school students) (Unpublished master's thesis). Çukurova Üniversitesi, Sosyal Bilimler Enstitüsü, Adana, Turkey.

Yıldırım, K., \& Tarım, K. (2008). Çoklu zekâ kuramı destekli kubaşık öğrenme yönteminin ilköğretim beşinci sınıf matematik dersinde akademik başarı ve hatırda tutma düzeyine etkisi (The effect of cooperative learning method supported by multiple intelligence theory on academic achievement and remembrance level in elementary fifth grade math class). İlköğretim Online, 7(1), 174-187.

Yıldırım, K., Tarım, K., \& İflazoğlu, A (2006). Çoklu zekâ kuramı destekli kubaşık öğrenme yönteminin matematik dersindeki akademik başarı ve kalıcılığa etkisi (The effect of cooperative learning method supported by multiple intelligence theory on academic achievement and retention in mathematics). Eğitimde Kuram ve Uygulama, 2(2), 81-96.

Yörük, İ. (2007). Çoklu zekâ kuramının ilköğretim din kültürü ve ahlak bilgisi dersi amaçlarının gerçekleşme düzeyine etkisi (The effect of multiple intelligence theory on the level of achievement of primary religious culture and ethics course objectives) (Unpublished master's thesis). Ankara Üniversitesi, Sosyal Bilimler Enstitüsü, Ankara, Turkey.

Yurt, E., \& Polat, S. (2015). The effectiveness of multiple intelligence applications on academic achievement: A metaanalysis. Journal of Social Studies Educational Research, 6(1), 84-122. https:/ / doi.org/10.17499/jsser.75161 


\section{APPENDIX 1}

The Effect of Learning-Teaching Process Based on Multiple Intelligence Theory on Academic Success, Statistics for Each Study and Forest Plot

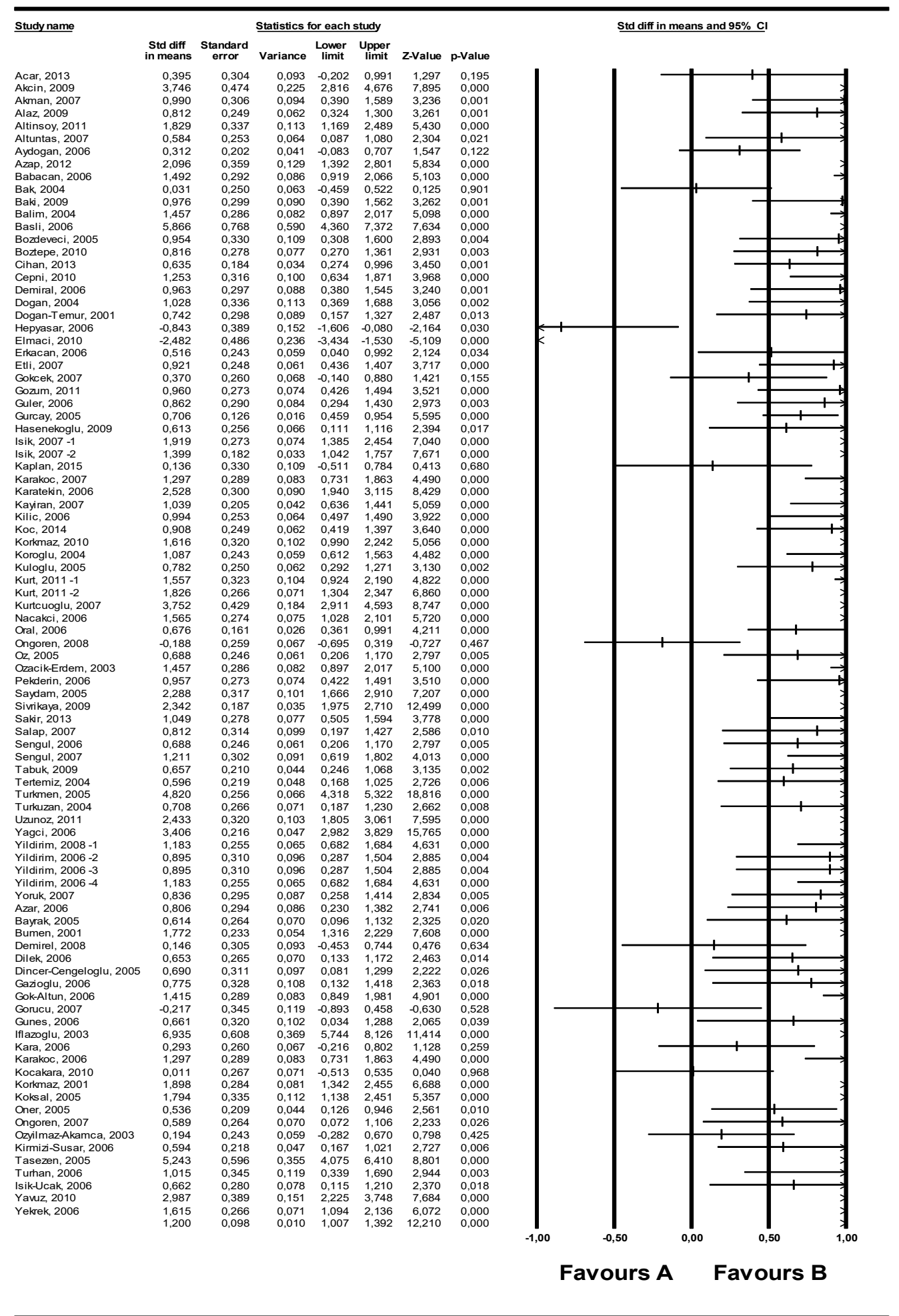

Meta Analysis 


\section{APPENDIX 2}

The Effect of Learning-Teaching Process Based on Multiple Intelligence on Attitude, Statistics for Each Study and Forest Plot

\begin{tabular}{|c|c|c|c|c|c|c|c|}
\hline \multirow[t]{2}{*}{ Study name } & \multicolumn{7}{|c|}{ Statistics for each study } \\
\hline & $\begin{array}{l}\text { Std diff } \\
\text { in means }\end{array}$ & $\begin{array}{l}\text { Standard } \\
\text { error }\end{array}$ & Variance & $\begin{array}{l}\text { Lower } \\
\text { limit }\end{array}$ & $\begin{array}{l}\text { Upper } \\
\text { limit }\end{array}$ & Z-Value & $\mathrm{p}$-Value \\
\hline Azar, 2006 & 0,285 & 0,284 & 0,081 & $-0,272$ & 0,843 & 1,004 & 0,316 \\
\hline Bayrak 2005 & 0,945 & 0,272 & 0,074 & 0,412 & 1,479 & 3,472 & 0,001 \\
\hline Bumen, 2001 & 1,871 & 0,247 & 0,061 & 1,387 & 2354 & 7,579 & 0,000 \\
\hline Demire, 2008 & $-0,068$ & 0,305 & 0,093 & $-0,666$ & 0,531 & $-0,222$ & 0,825 \\
\hline Dilek 2006 & 0,294 & 0,260 & 0,067 & $-0,215$ & 0,803 & 1,132 & 0,258 \\
\hline Dincer-Cengeloglu, 2005 & 0,445 & 0,306 & 0,093 & $-0,154$ & 1,044 & 1,456 & 0,145 \\
\hline Alz, 2008 & 0,621 & 0,245 & 0,000 & 0,141 & 1,102 & 2,534 & 0,011 \\
\hline Ayaydin,2011 & 0,352 & 0,256 & 0,066 & $-0,150$ & 0,853 & 1,374 & 0,169 \\
\hline Epcacan, 2013 & $-1,372$ & 0,297 & 0,088 & $-1,954$ & $-0,790$ & $-4,619$ & 0,000 \\
\hline pengü,2008 & 0,773 & 0,248 & 0,061 & 0,287 & 1,258 & 3,118 & 0,002 \\
\hline Tabuk, 2010 & 0,669 & 0,181 & 0,033 & 0,314 & 1,024 & 3,693 & 0,000 \\
\hline Gezioglu, 2006 & 1,632 & 0,365 & 0,133 & 0,917 & 2,348 & 4,470 & 0,000 \\
\hline GokAttun, 2006 & 0,567 & 0,263 & 0,009 & 0,051 & 1,083 & 2,153 & 0,031 \\
\hline Gorucu, 2007 & $-0,966$ & 0,363 & 0,132 & $-1,677$ & $-0,254$ & $-2,661$ & 0,008 \\
\hline Qnes, 2006 & 0,510 & 0,317 & 0,100 & $-0,111$ & 1,131 & 1,610 & 0,107 \\
\hline |flazoglu, 2003 & 2,940 & 0,331 & 0,110 & 2,291 & 3,589 & 8,878 & 0,000 \\
\hline Karakoc, 2006 & 0,597 & 0,268 & 0,072 & 0,071 & 1,123 & 2,225 & 0,026 \\
\hline Korkmaz, 2001 & 1,891 & 0,284 & 0,080 & 1,335 & 2447 & 6,669 & 0,000 \\
\hline Koksal, 2005 & 0,617 & 0,289 & 0,084 & 0,050 & 1,185 & 2,132 & 0,033 \\
\hline Oner, 2005 & 0,279 & 0,210 & 0,044 & $-0,132$ & 0,690 & 1,330 & 0,183 \\
\hline Ongoren, 2007 & $-0,144$ & 0,259 & 0,067 & $-0,650$ & 0,363 & $-0,556$ & 0,578 \\
\hline Ozilmaz-Akamca, 2003 & 0,674 & 0,249 & 0,062 & 0,185 & 1,162 & 2,702 & 0,007 \\
\hline Krmizi-Susar, 2006 & 0,423 & 0,216 & 0,046 & 0,000 & 0,845 & 1,960 & 0,060 \\
\hline Tasezen, 2005 & 14,003 & 1,429 & 2,041 & 11,203 & 16,803 & 9,802 & 0,000 \\
\hline Turhan, 2006 & 1,214 & 0,353 & 0,125 & 0,522 & 1,906 & 3,438 & 0,001 \\
\hline |sik-Ucak 2006 & 0,727 & 0,281 & 0,079 & 0,177 & 1,278 & 2,588 & 0,010 \\
\hline Yauz, 2010 & $-0,395$ & 0,270 & 0,073 & $-0,923$ & 0,134 & $-1,462$ & 0,144 \\
\hline \multirow{2}{*}{ Yeleck, 2006} & 1,482 & 0,261 & 0,068 & 0,971 & 1,993 & 5,684 & 0,000 \\
\hline & 0,770 & 0,176 & 0,031 & 0,426 & 1,115 & 4,382 & 0,000 \\
\hline
\end{tabular}

\section{$\underline{\text { Std diff in means and } 95 \% \mathrm{Cl}}$}

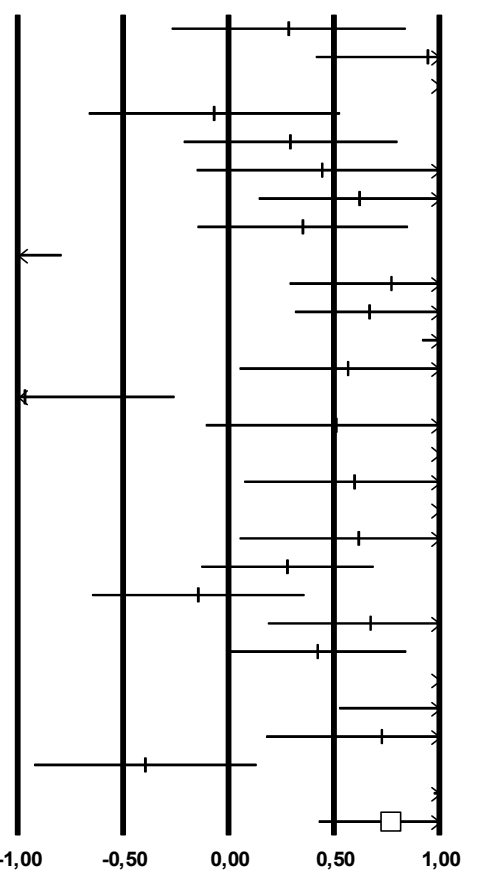

Favours A Favours B 